\title{
Flame Pyrolysis Synthesis of Mixed Oxides for Glycerol Steam Reforming
}

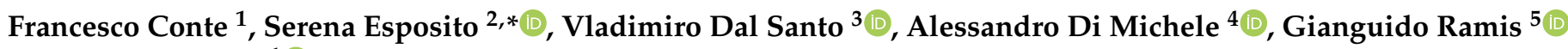 \\ and Ilenia Rossetti ${ }^{1}$ (i)
}

Citation: Conte, F.; Esposito, S.; Dal Santo, V.; Di Michele, A.; Ramis, G.; Rossetti, I. Flame Pyrolysis Synthesis of Mixed Oxides for Glycerol Steam Reforming. Materials 2021, 14, 652. https://doi.org/10.3390/ma14030652

Academic Editor: Sergio

Morales-Torres

Received: 18 December 2020

Accepted: 25 January 2021

Published: 31 January 2021

Publisher's Note: MDPI stays neutral with regard to jurisdictional claims in published maps and institutional affiliations.

Copyright: (c) 2021 by the authors. Licensee MDPI, Basel, Switzerland. This article is an open access article distributed under the terms and conditions of the Creative Commons Attribution (CC BY) license (https:/ / creativecommons.org/licenses/by/ $4.0 /)$.
1 Chemical Plants and Industrial Chemistry Group, Dip. Chimica, Università degli Studi di Milano, INSTM Unit Milano-Università and CNR-SCITEC, Via C. Golgi, 19, 20133 Milano, Italy; francesco.conte@unimi.it (F.C.); ilenia.rossetti@unimi.it (I.R.)

2 Dipartimento di Scienza Applicata e Tecnologia e Unità INSTM Torino-Politecnico Corso Duca degli Abruzzi, 24, 10129 Torino, Italy

3 CNR-Istituto di Scienze e Tecnologie Chimiche “Giulio Natta”, Via C. Golgi 19, 20133 Milano, Italy; vladimiro.dalsanto@scitec.cnr.it

4 Dip. Fisica e Geologia, Università degli Studi di Perugia, Via Pascoli, 06123 Perugia, Italy; alessandro.dimichele@collaboratori.unipg.it

5 Dip. di Ingegneria Civile, Chimica e Ambientale, Università degli Studi di Genova and INSTM Unit Genova, Via all'Opera Pia 15A, 16145 Genoa, Italy; gianguidoramis@unige.it

* Correspondence: serena_esposito@polito.it

\begin{abstract}
Flame spray pyrolysis was used to produce nanosized Ni-based catalysts starting from different mixed oxides. $\mathrm{LaNiO}_{3}$ and $\mathrm{CeNiO}_{3}$ were used as base materials and the formulation was varied by mixing them or incorporating variable amounts of $\mathrm{ZrO}_{2}$ or SrO during the synthesis. The catalysts were tested for the steam reforming of glycerol. One of the key problems for this application is the resistance to deactivation by sintering and coking, which may be increased by (1) improving $\mathrm{Ni}$ dispersion through the production of a Ni-La or Ni-Ce mixed oxide precursor, and then reduced; (2) using an oxide as $\mathrm{ZrO}_{2}$, which established a strong interaction with $\mathrm{Ni}$ and possesses high thermal resistance; (3) decreasing the surface acidity of $\mathrm{ZrO}_{2}$ through a basic promoter/support, such as $\mathrm{La}_{2} \mathrm{O}_{3}$; and (4) adding a promoter/support with very high oxygen mobility such as $\mathrm{CeO}_{2}$. A further key feature is the use of a high temperature synthesis, such as flame spray pyrolysis, to improve the overall thermal resistance of the oxides. These strategies proved effective to obtain active and stable catalysts at least for $20 \mathrm{~h}$ on stream with very limited coke formation.
\end{abstract}

Keywords: glycerol steam reforming; $\mathrm{H}_{2}$ production; flame spray pyrolysis; $\mathrm{Ni}$ mixed oxide catalysts; coking

\section{Introduction}

Hydrogen is gaining increasing importance as an energy vector, as a means to store energy and to convert it through highly efficient devices, such as fuel cells. However, $\mathrm{H}_{2}$ is not present as such in nature and it has to be produced [1,2]. Industrially, it is mainly obtained from the steam reforming of hydrocarbons, but currently, the research is attempting to adapt this process to renewable sources [3]. Among these, bioethanol, coming from the fermentation of biomasses, and glycerol, a by-product from the trans-esterification of triglycerides for biodiesel production (Figure 1), are among the most studied $[4,5]$.

The current worldwide production of biodiesel is ca. 702 thousand barrels/day [6]. The reaction leaves ca. $10 \mathrm{wt} \%$ glycerol as a byproduct per unit weight of biodiesel produced [7-10]. However, crude glycerol contains mineral impurities (phosphorous, calcium, alkali metals, unreacted fatty acids and methanol), which impose expensive purification to achieve practically exploitable purity for the conventional glycerol market (food and pharma industry). Furthermore, the latter market is unable to sustain the increasing availability of glycerol. The development of glycerol transformation routes 
that have a large potential volume of production and do not require heavy purification of the feed is envisaged and, among these, the production of hydrogen by steam reforming appears promising [11].

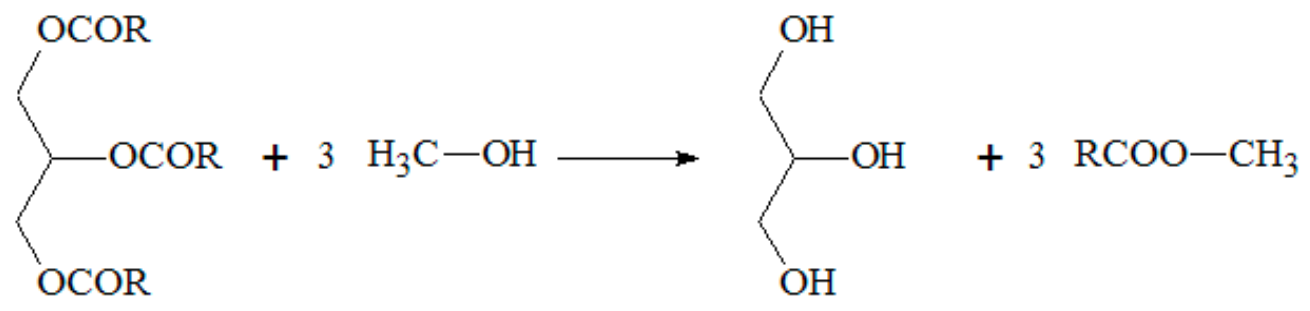

Figure 1. Reaction equation of the transesterification process.

Glycerol steam reforming (GSR) occurs through the following stoichiometry:

$$
\mathrm{C}_{3} \mathrm{H}_{8} \mathrm{O}_{3}+3 \mathrm{H}_{2} \mathrm{O} \rightarrow 3 \mathrm{CO}_{2}+7 \mathrm{H}_{2} \quad \Delta \mathrm{H}=+128 \mathrm{~kJ} / \mathrm{mol}
$$

which may be seen as the combination of syngas production and the water gas shift reaction:

$$
\begin{array}{cc}
\mathrm{C}_{3} \mathrm{H}_{8} \mathrm{O}_{3} \rightarrow 3 \mathrm{CO}+4 \mathrm{H}_{2} & \Delta \mathrm{H}=+251 \mathrm{~kJ} / \mathrm{mol} \\
\mathrm{CO}+\mathrm{H}_{2} \mathrm{O} \leftrightarrows \mathrm{CO}_{2}+\mathrm{H}_{2} & \Delta \mathrm{H}=-41 \mathrm{~kJ} / \mathrm{mol}
\end{array}
$$

Undesired parasitic reactions may also occur, among which those leading to carbon deposition are of particular concern.

Hydrogen yield depends on operating conditions, the nature of active metal, and the catalyst support. The most studied catalysts for steam reforming of glycerol are based on noble ( $\mathrm{Rh}, \mathrm{Ru}, \mathrm{Pt}, \mathrm{Pd})$ and non noble $(\mathrm{Ni}, \mathrm{Cu})$ metals. Among them, Ni catalyst is the most attractive for its own ability in the cleavage of the $\mathrm{C}-\mathrm{C}, \mathrm{C}-\mathrm{H}$, and $\mathrm{H}-\mathrm{O}$ bonds [12-19]. Besides, it is cost-effective, but suffers deactivation in long-term operations due to coke formation and metal sintering [20]. Therefore, synthesis of suitable catalysts is addressed towards the suppression of coke formation and sintering of the metal particles during reforming. Nowadays, these limitations are not yet overcome and the preparation of a stable catalyst for glycerol steam reforming is still a challenge.

Different approaches have been employed to improve the performance of nickelbased catalysts, most of them based on tailoring the physical properties. High surface area with suitable nickel dispersion along with small particle size and a strong metal-support interaction are seen as the key factors for the synthesis of highly active catalysts. From this point of view, supports play an important role in terms of hydrogen selectivity and catalyst stability.

Alumina is one of the most used supports for its mechanical and physical properties. Lima et al. [12] studied the effect of $\mathrm{Mg}$ addition to decrease the acid character of alumina reported to favor coke formation. The presence of $\mathrm{Mg}$ also led to a better $\mathrm{Ni}$ dispersion through the formation of a spinel structure, $\mathrm{Mg}(\mathrm{Ni}) \mathrm{Al}_{2} \mathrm{O}_{4}$. The authors also demonstrated the non-negligible influence of the preparation method by comparing impregnated and co-precipitated samples: the partial replacement of $\mathrm{Ni}$ with $\mathrm{Mg}$ had a greater effect on the co-precipitated samples with respect to impregnated catalysts.

A different approach was proposed by Yancheshmeh et al. [13], who exploited the activity of $\mathrm{NiAl}_{2} \mathrm{O}_{4}$-based catalysts. The better dispersion achieved embedding $\mathrm{Ni}$ in a spinel structure encounters the difficulty of a limit reduction with respect to a supported $\mathrm{NiO}$. To overcome this limitation, the authors investigated the effect of a novel solvothermal method achieving high $\mathrm{H}_{2}$ yields (76\%) and 95\% glycerol conversion into gaseous products.

Another promising candidate as catalytic support is $\mathrm{ZrO}_{2}$ in name of its thermal stability and surface properties [21]. The effect of the crystalline polymorphs on the steam reforming of glycerol was studied by Dahdah et al. [14]; nickel was impregnated on synthesized tetragonal zirconia and on commercial monoclinic zirconia. Ni-(monoclinic)zirconia 
showed enhanced nickel reducibility, which positively affected hydrogen yields and glycerol conversion.

The replacement in crystalline lattice of $\mathrm{Zr}^{4+}$ with lower valence cations $\left(\mathrm{Mg}^{2+}, \mathrm{Ca}^{2+}\right.$, $\left.\mathrm{Y}^{3+}, \mathrm{La}^{3+}\right)$ produces oxygen vacancies [22,23]. The concentration of oxygen defects and the extent of oxygen mobility are crucial in many applications of doped zirconia. Charisiou et al. [15] tested yttria-stabilized zirconia as catalytic support in the GSR process. $\mathrm{Y}_{2} \mathrm{O}_{3}$ modified $\mathrm{ZrO}_{2}$ led to more reducible $\mathrm{NiO}$, less sintering phenomena, and higher stability. Moreover, whereas graphitic structures are identified on unpromoted zirconia, amorphous carbon was deposited on $\mathrm{Ni} / \mathrm{YZr}$, which are more easily oxidized during the reaction. The effect of a highly defective $\mathrm{La}_{2} \mathrm{O}_{3}-\mathrm{ZrO}_{2}$ support was also tested by Veiga et al. [16]. Here, $15 \%$ Ni-La-Zr was used as catalyst for GSR using a feedstock of glycerol obtained directly from an industrial biodiesel plant as a by-product. The authors observed a strong correlation between the calcination temperature and the amount of carbon deposits. The lowest amount of carbon deposits for the catalyst calcined at $850{ }^{\circ} \mathrm{C}$ was correlated with the formation of a pyrochlore-type structured $\mathrm{La}_{2} \mathrm{Zr}_{2} \mathrm{O}_{7}$ with a partial substitution of nickel ions into $\mathrm{Zr}$ sites. The presence of defects and the subsequent formation of mobile oxygen vacancies favored the oxidation of carbon deposits during the reaction.

The effects of various supports, different promoters $(\mathrm{K}, \mathrm{Ca}, \mathrm{Sr}, \mathrm{Ce}, \mathrm{La}, \mathrm{Cr}, \mathrm{Fe})$, and process conditions were, recently, illustrated by a review of Saeidabad et al. [17]. Among the different catalytic formulations, perovskite type oxide appears intriguing for their unique crystal structure, which promotes the formation of metallic particles with high dispersion, enhanced hydrogen production, and improved coke resistance.

In addition to the structural and physicochemical properties of the support, the adopted synthesis approach is also a powerful tool for obtaining highly active and stable catalysts. A valuable and intriguing synthesis route is represented by the use of metalorganic frameworks as precursors of metal oxides-based materials [24-26].

Among the possible active phases, $\mathrm{Pt}$ and other noble metals are effective for this reaction and are used for aqueous phase reforming, but they are prone to deactivation and expensive. Ni offers the advantage of a reasonable activity and selectivity, coupled with smaller cost with respect to noble metals for this application. However, Ni readily forms carbon nanotubes from carbide intermediates and we have previously demonstrated that, during the steam reforming of bioethanol, this may lead to the detachment of Ni particles, with irreversible catalyst deactivation [27-38]. We have already demonstrated that a strong metal-support interaction also helps keep $\mathrm{Ni}$ well dispersed under the working conditions for the steam reforming of bioethanol.

Acidic supports such as alumina, the most used for methane steam reforming, are more prone to coking for this application, as dehydration and condensation may occur over the acidic sites. Therefore, different strategies may be developed to limit this phenomenon, e.g., the addition of basic oxides $(\mathrm{Mg}, \mathrm{La}, \mathrm{Ce}, \mathrm{Zr})[20,39,40]$ or the use of supports intrinsically characterised by high oxygen mobility, such as $\mathrm{CeO}_{2}$ or $\mathrm{Ce}_{1-\mathrm{x}} \mathrm{Zr}_{\mathrm{x}} \mathrm{O}_{2}$.

In order to improve the dispersion of $\mathrm{Ni}$ over these oxides, mixed oxide formulations can be used, such as $\mathrm{La}_{1-\mathrm{x}} \mathrm{Ce}_{\mathrm{x}} \mathrm{NiO}_{3}$ (with $\mathrm{x}=0,0.1,0.3,0.7$ ), to achieve a suitable activity and resistance, at least for a limited time-on-stream [41-43].

Therefore, in the present work, we have prepared and characterised a set of Nibased catalysts supported over mixed oxides. The selected synthesis procedure was flame spray pyrolysis (FP), which should guarantee suitable thermal resistance thanks to the high temperature reached during the synthesis. The Ni active phase was added directly during the flame preparation, possibly in form of mixed oxide, and then reduced. The FP method already proved effective for the steam reforming of bioethanol to improve the ni dispersion and therma resistance for a set of $\mathrm{LaNiO}_{3}$ samples [44]. Alternatively, we tested the impregnation of Ni over the same supports prepared by FP. The performance and resistance to deactivation were tested for the steam reforming of glycerol. 


\section{Experimental}

\subsection{Materials' Preparation}

The catalysts were prepared by flame spray pyrolysis (FP) [44,45]. The precursors of the oxide catalysts were dissolved with $0.1 \mathrm{M}$ concentration in a 1:1 (vol/vol) solution of propionic acid pur. 97\% (Aldrich-Merck Life Science S.r.l., Italy) and o-xylene pur. 97\% (Aldrich-Merck Life Science S.r.l., Italy), acting as a fuel for the flame and the solution injected through a syringe pump (Harvard, mod. 975, Harvard Apparatus, Holliston, MA, USA) through a needle with a liquid flow of $2.2 \mathrm{~mL} / \mathrm{min}$. The needle is inserted in a self-designed burner, where it is surrounded by a coaxial flow of $5 \mathrm{NL} / \mathrm{min}$ of $\mathrm{O}_{2}$, with a 1.5 bar pressure drop across the nozzle, and the mixture is ignited by a ring of flamelets $\left(\mathrm{CH}_{4}\right.$ and $\mathrm{O}_{2}$ with flowrate of 0.5 and $1 \mathrm{~L} / \mathrm{min}$, respectively). Gas flows are regulated by means of MKS, mod. 1259 massflowmeters (MKS Instruments, Inc., Andover, MA, USA). The powder is collected on a pyrex bell surrounding the burner.

The precursors used were as follows: $\mathrm{La}\left(\mathrm{CH}_{3} \mathrm{COO}\right)_{3} \cdot \mathrm{H}_{2} \mathrm{O}$ pur. $99.9 \%$ (Aldrich-Merck Life Science S.r.l., Italy), $\mathrm{Ni}\left(\mathrm{CH}_{3} \mathrm{COO}\right)_{2} \cdot 4 \mathrm{H}_{2} \mathrm{O}$ pur. $98 \%$ (Aldrich-Merck Life Science S.r.l., Italy), $\mathrm{Zr}\left(\mathrm{C}_{5} \mathrm{H}_{7} \mathrm{O}_{2}\right)_{4}$ pur. $99 \%$ (Aldric-hMerck Life Science S.r.l., Italy), $\mathrm{Sr}\left(\mathrm{CH}_{3} \mathrm{COO}\right)_{2}$ pur. $99.9 \%$ (Aldrich-Merck Life Science S.r.l., Italy), and $\mathrm{Ce}\left(\mathrm{CH}_{3} \mathrm{COO}\right)_{3} \cdot \mathrm{H}_{2} \mathrm{O}$ pur. $99.9 \%$ (Aldrich-Merck Life Science S.r.l., Italy).

The catalyst formulations prepared are reported in Table 1 . The samples with the symbol $10 \mathrm{wt} \% \mathrm{Ni} /$ Oxide were prepared by impregnation of the metal, from the same precursor, over the FP-synthesised oxide, used as support. Here, $10 \mathrm{wt} \%$ metal loading was selected from a previous investigation [28]. The formulations where Ni is included in the oxide formula were prepared as mixed oxides. The metallic $\mathrm{Ni}$ active phase was achieved upon reduction in the activation step.

Table 1. Composition and textural properties of the catalysts prepared by flame spray pyrolysis (FP). SSA = specific surface area, evaluated through the Brunauer Emmet Teller model. Micropore SSA evaluated from the t-plot method.

\begin{tabular}{ccccc}
\hline Composition & Code & $\begin{array}{c}\text { BET SSA } \\
(\mathbf{m} \text { /g) }\end{array}$ & $\begin{array}{c}\text { Micropore SSA } \\
(\mathbf{m} \text { /g) }\end{array}$ & $\begin{array}{c}\text { Crystal Size } \\
(\mathbf{n m})\end{array}$ \\
\hline $\mathrm{La}_{0.3} \mathrm{Zr}_{0.7} \mathrm{NiO}_{3}$ & $\mathrm{a}$ & 63 & 11 & 28 \\
\hline $10 \mathrm{wt} \% \mathrm{Ni} /\left(0.3 \mathrm{La}_{2} \mathrm{O}_{3}-0.7 \mathrm{ZrO}_{2}\right)$ & $\mathrm{b}$ & 44 & 4 & 35 \\
\hline $\mathrm{La}_{0.8} \mathrm{Sr}_{0.2} \mathrm{NiO}_{3}$ & $\mathrm{c}$ & 56 & 13 & 17 \\
\hline $\mathrm{CeNiO}_{3}$ & $\mathrm{~d}$ & 62 & 14 & 22 \\
\hline $\mathrm{La}_{0.3} \mathrm{Ce}_{0.7} \mathrm{NiO}_{3}$ & $\mathrm{e}$ & 57 & 14 & 20 \\
\hline $10 \mathrm{wt} \% \mathrm{Ni} /\left(0.3 \mathrm{La}_{2} \mathrm{O}_{3}-0.7 \mathrm{CeO}_{2}\right)$ & $\mathrm{f}$ & 46 & 7 & 27 \\
\hline $\mathrm{LaNiO}_{3}$ & $\mathrm{~g}$ & 53 & 9 & 14 \\
\hline
\end{tabular}

\subsection{Catalysts' Characterisation}

The catalysts $(0.1 \mathrm{~g})$ were characterised by temperature programmed reduction (TPR) with a Micromeritics Pulse Chemisorb 2700 (Norcross, GA) with TCD (ThermoConductivity) detector, by heating $8{ }^{\circ} \mathrm{C} / \mathrm{min}$ up to $950{ }^{\circ} \mathrm{C}$. The catalysts were pretreated in oxygen flow at $250{ }^{\circ} \mathrm{C}$ and then analysed in $20 \mathrm{~mL} / \mathrm{min}$ of a $5 \mathrm{vol} \% \mathrm{H}_{2} / \mathrm{Ar}$ mixture.

The specific surface area of the catalysts was determined with by $\mathrm{N}_{2}$ adsorption/ desorption with a Micromeritics ASAP2010 instrument (Norcross, GA) after outgassing the sample overnigth at $300^{\circ} \mathrm{C}$.

The catalysts were characterized by X-ray diffraction (XRD) on a Philips PW3020 powder diffractometer (Philips, Eindhoven, NL).

Morphologic analysis, obtained by Scanning Electron Microscopy (SEM) was carried out with an Electron Scanning Microscope Philips XL-30CP (Philips, Eindhoven, NL). Elemental composition was determined using the Energy dispersive X-ray analysis (EDS) with an EDAX/DX4 detector. 
Trasmission Electron Microscopy (TEM) images were obtained using a Philips 208 Transmission Electron Microscope (Philips, Eindhoven, NL). The samples were prepared by putting one drop of an ethanol dispersion of the catalysts on a copper grid pre-coated with a Formvar film and dried in air.

Thermal Gravimetric Analysis (TGA) analysis was carried out on $10 \mathrm{mg}$ of spent sample (resolution $0.001 \mathrm{mg}$ ) with a Perkin Elmer TGA7 apparatus (Perkin Elmer Italia, Milano, Italy), by heating $2^{\circ} \mathrm{C} / \mathrm{min}$ from 50 to $1000^{\circ} \mathrm{C}$ to quantify the amount of carbon residuals over the catalyst.

\subsection{Catalytic Activity Testing}

Activity testing was performed in a quartz tubular reactor, with $0.9 \mathrm{~cm}$ inner diameter, loaded with $0.200 \mathrm{~g}$ of catalyst, diluted 1:1 (wt/wt) with quartz of the same size $(354-500 \mu \mathrm{m})$. The catalyst bed is separated by quartz wool from the top fillers, where, in the evaporative zone, metal beads are used $(1.2-4.8 \mathrm{~mm})$. The reactor is heated by an electric oven, controlled by a Eurotherm mod. 2408 (Eurotherm, Worthing, UK) TIC, Temperature Indicator and Controller, for the reactive zone, while the upper evaporative zone is heated separately with an Eurotherm mod. 808 (Eurotherm, Worthing, UK ) TIC. The reactor is connected with gas lines that can feed either $\mathrm{He}(30 \mathrm{~mL} / \mathrm{min}$ during activity testing) or $\mathrm{H}_{2}$. A $10 \mathrm{wt} \%$ aqueous solution of glycerol is pumped with a KNF-Lab Stepdos 03S (KNF, Stockholm, Sweden) with a flow rate of $0.060 \mathrm{~mL} / \mathrm{min}$. The liquid products are condensed at the reactor outlet through a cryogenic bath $\left(1.5^{\circ} \mathrm{C}\right)$, while the gaseous products pass through a flowmeter (Bios $530 \mathrm{~L}$ ) and then are directly fed to a Gas Chromatograph (Agilent mod. 6890N, Palo Alto, CA, USA) for periodic samplings.

The catalyst is activated in $30 \mathrm{~mL} / \mathrm{min}$ of $\mathrm{H}_{2}$ by heating by $10^{\circ} \mathrm{C} / \mathrm{min}$ up to $700{ }^{\circ} \mathrm{C}$, and kept for $1 \mathrm{~h}$. The temperature is then decreased to $650^{\circ} \mathrm{C}$ in the reaction zone, while the evaporating zone is maintained at $250{ }^{\circ} \mathrm{C}$. The tests were typically carried out for $20 \mathrm{~h}$ on stream, if not specified otherwise. The results report glycerol conversion; hydrogen yield; and the selectivities to $\mathrm{CO}, \mathrm{CO}_{2}$, and $\mathrm{CH}_{4}$ if relevant. When needed, the condensed products were analysed with a GC-MS Hewlett Packard 5971 Series (Agilent, Palo Alto, CA, USA) at the end of the reaction. Replicates were reproducible within $5 \%$ error.

\section{Results and Discussion}

\subsection{Catalysts' Characterisation}

The specific surface area of the catalysts was between 44 and $63 \mathrm{~m}^{2} / \mathrm{g}$ (Table 1), with very limited micropores contribution, because the FP procedure leads to the formation of dense nanoparticles.

SEM and TEM analysis revealed uniform nanoparticles with size lower than $20 \mathrm{~nm}$ (Figure 2). Some bigger agglomerates were visible only for sample $10 \mathrm{wt} \% \mathrm{Ni} /\left(0.3 \mathrm{La}_{2} \mathrm{O}_{3}-\right.$ $0.7 \mathrm{ZrO}_{2}$ ), for which bigger hollow spheres were evident in some TEM pictures (Figure 2).

The nominal composition of the samples was checked through EDS analysis, considering the atomic\% (at \%). Mapping the sample surface revealed quite uniform distribution of all the elements over the surface of the catalyst. When considering spot analysis, the average composition of the samples was in general confirmed.

For instance, for sample $\mathrm{La}_{0.3} \mathrm{Ce}_{0.7} \mathrm{NiO}_{3}(\mathrm{La}=6.61 \mathrm{at} \%, \mathrm{Ce}=15.36$ at $\%, \mathrm{Ni}=21.39$ at $\%)$, the atomic ratio $\mathrm{La} /(\mathrm{La}+\mathrm{Ce})$ was 0.301 , while $(\mathrm{La}+\mathrm{Ce}) / \mathrm{Ni}$ was 1.03 . Similarly, for sample $\mathrm{La}_{0.8} \mathrm{Sr}_{0.2} \mathrm{NiO}_{3}(\mathrm{La}=21.4$ at $\%, \mathrm{Sr}=5.1 \mathrm{at} \%, \mathrm{Ni}=23.7 \mathrm{at} \%)$, the atomic ratios were $\mathrm{Sr} /(\mathrm{Sr}+$ $\mathrm{La})=0.19$ and $(\mathrm{La}+\mathrm{Sr}) / \mathrm{Ni}=1.12$.

On the contrary, the $\mathrm{Zr}$-containing samples revealed an unbalanced composition of the oxide, as the mixed phase was not formed and phase segregation occurred (see XRD results), resulting in a local composition different from the nominal one. For instance, the EDS analysis of sample $10 \mathrm{wt} \% \mathrm{Ni} /\left(0.3 \mathrm{La}_{2} \mathrm{O}_{3}-0.7 \mathrm{ZrO}_{2}\right)(\mathrm{La}=5.8 \mathrm{at} \%, \mathrm{Zr}=70.7 \mathrm{at} \%$, $)$ revealed that the atomic ratio $\mathrm{La} / \mathrm{Zr}$ was 0.08 instead of the nominal 0.42 and Ni content was $4.2 \mathrm{wt} \%$. Similar results were evident for sample $\mathrm{La}_{0.3} \mathrm{Zr}_{0.7} \mathrm{NiO}_{3}(\mathrm{La}=4.4$ at $\%, \mathrm{Zr}=52.5$ at $\%$, 
$\mathrm{Ni}=17.6 \mathrm{at} \%)$, for which the $\mathrm{La} / \mathrm{Ni}$ average atomic ratio was 0.25 instead of $0.3, \mathrm{but} \mathrm{La} /(\mathrm{La}$ $+\mathrm{Zr}$ ) was 0.08 with respect to the nominal 0.3.
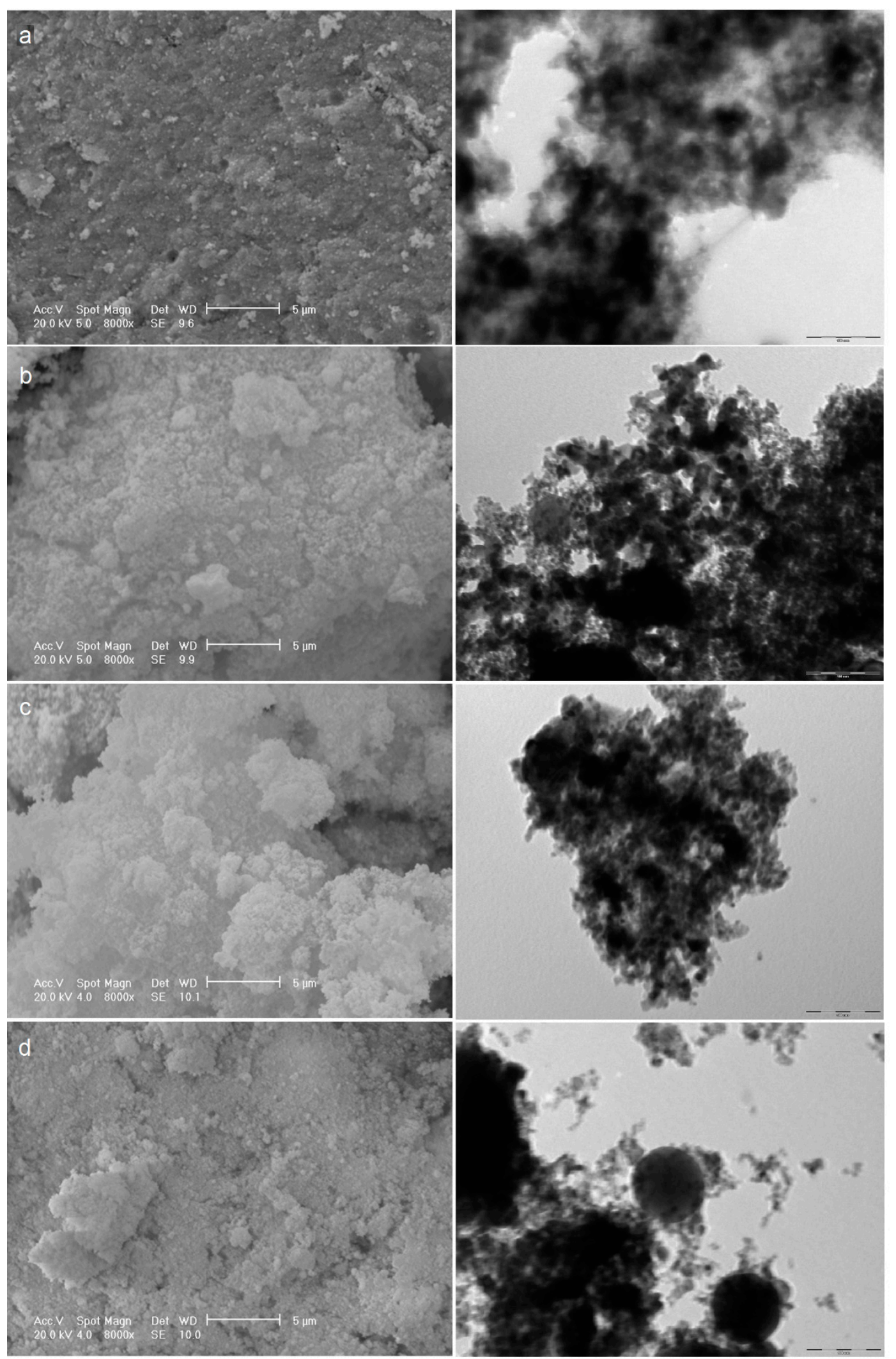

Figure 2. SEM (left, marker size $5 \mu \mathrm{m}$ ) and TEM (right, marker size $100 \mathrm{~nm}$ ) micrographs of selected samples (a) $\mathrm{La}_{0.3} \mathrm{Zr}_{0.7} \mathrm{NiO}_{3} ;$ (b) $\mathrm{La}_{0.3} \mathrm{Ce}_{0.7} \mathrm{O}_{3} ;$ (c) $\mathrm{La}_{0.8} \mathrm{Sr}_{0.2} \mathrm{NiO}_{3} ;$ (d) $10 \mathrm{wt} \% \mathrm{Ni} /\left(0.3 \mathrm{La}_{2} \mathrm{O}_{3}-0.7 \mathrm{ZrO}_{2}\right)$. 
The particle size distribution statistics are reported in Figure 3. The average particle size is similar for all the samples and sufficiently sharp, except for sample $10 \mathrm{wt} \%$ $\left.\mathrm{Ni} /\left(0.3 \mathrm{La}_{2} \mathrm{O}_{3}-0.7 \mathrm{ZrO}\right)_{2}\right)$. The latter showed a narrow distribution centre as well on ca. $8 \mathrm{~nm}$ when excluding the bigger particles, while, when including the widest hollow particles, a broader distribution was obtained.
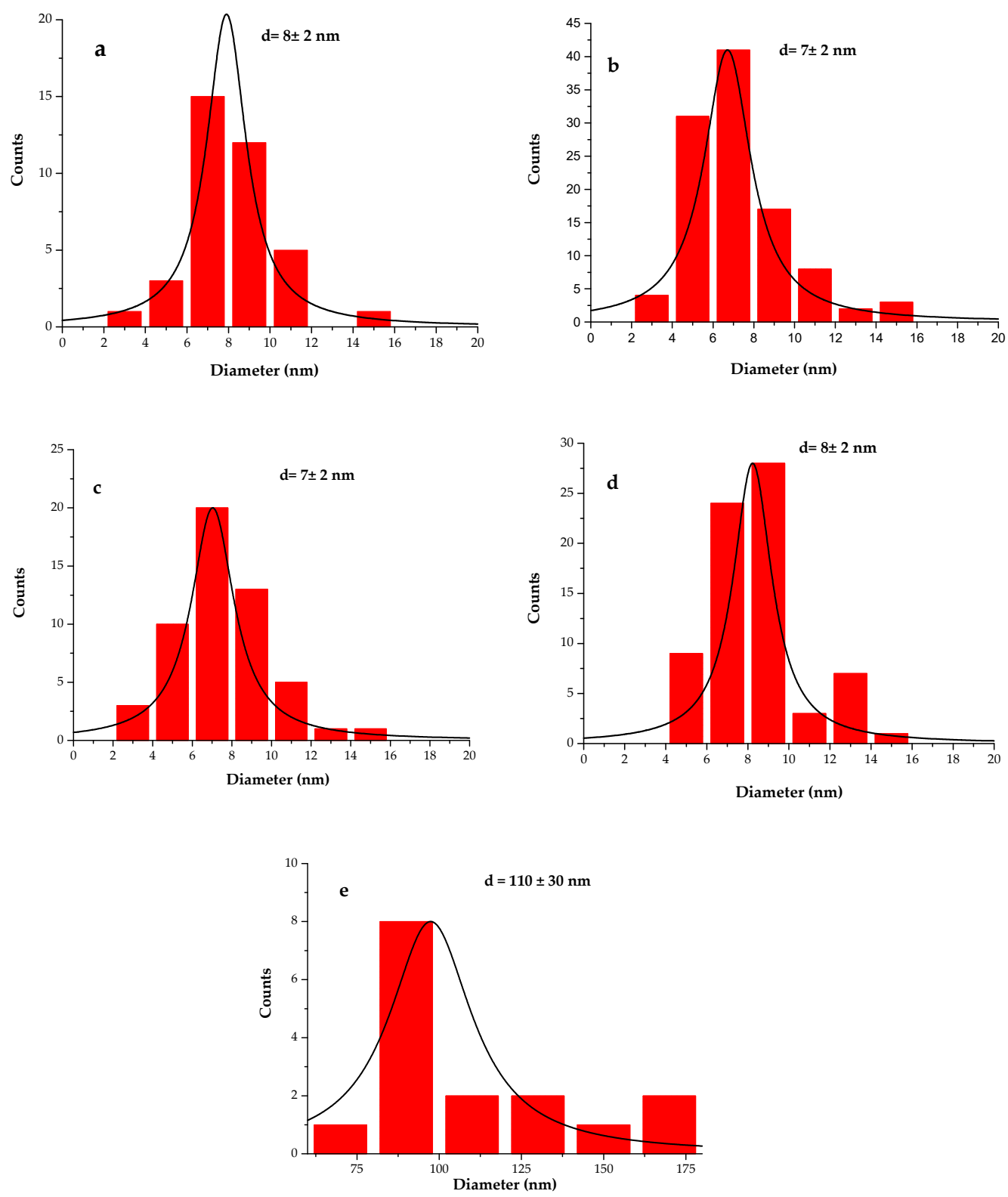

Figure 3. Particle size distributions of the selected samples (a) $\mathrm{La}_{0.3} \mathrm{Zr}_{0.7} \mathrm{NiO}_{3} ;$ (b) $\mathrm{La}_{0.3} \mathrm{Ce}_{0.7} \mathrm{NiO}_{3}$; (c) $\mathrm{La}_{0.8} \mathrm{Sr}_{0.2} \mathrm{NiO}_{3} ;$ (d) $10 \mathrm{wt} \% \mathrm{Ni}\left(0.3 \mathrm{La}_{2} \mathrm{O}_{3}-0.7 \mathrm{ZrO} 2\right)$; (e) $10 \mathrm{wt} \% \mathrm{Ni}\left(0.3 \mathrm{La}_{2} \mathrm{O}_{3}-0.7 \mathrm{ZrO}_{2}\right)$.

The nature of the phases formed was investigated by XRD (Figure 4) and phase attribution was done through comparison with powder diffraction files (PDF, Centre for Diffraction Data, ICDD, charts [46]). The samples with formal formula $\mathrm{La}_{0.3} \mathrm{Zr}_{0.7} \mathrm{NiO}_{3}$ and $10 \mathrm{wt} \% \mathrm{Ni} /\left(0.3 \mathrm{La}_{2} \mathrm{O}_{3}-0.7 \mathrm{ZrO}_{2}\right)$ were confirmed to be constituted of a heterogeneous phase mixture mainly containing $\mathrm{ZrO}_{2}$ and $\mathrm{NiO}$. The latter phase was predominantly evident in the former sample owing to the higher $\mathrm{Ni}$ content than the latter sample, where $\mathrm{Ni}$ was added by impregnation in a lower amount. 

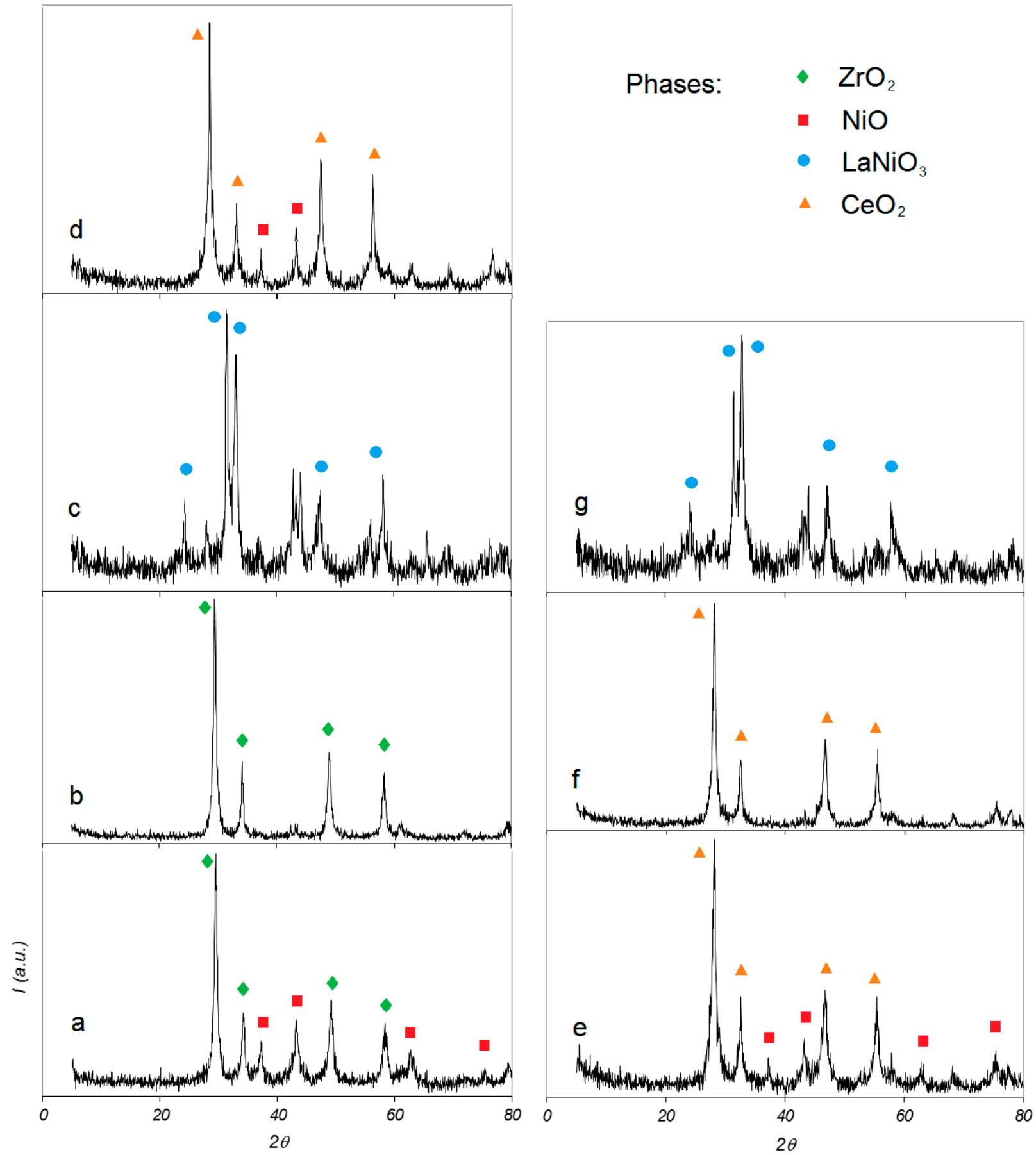

Figure 4. XRD patterns of the flame spray pyrolysis (FP)-prepared catalysts.(a) $\mathrm{La}_{0.3} \mathrm{Zr}_{0.7} \mathrm{NiO}_{3} ;$ (b) $10 \mathrm{wt} \% \mathrm{Ni} /\left(0.3 \mathrm{La} \mathrm{O}_{3}-\right.$ $\left.0.7 \mathrm{ZrO}_{2}\right) ;(\mathbf{c}) \mathrm{La}_{0.8} \mathrm{Sr}_{0.2} \mathrm{NiO}_{3} ;$ (d) $\mathrm{CeNiO}_{3} ;(\mathbf{e}) \mathrm{La}_{0.3} \mathrm{Ce}_{0.7} \mathrm{NiO}_{3} ;$ (f) $10 \mathrm{wt} \% \mathrm{Ni} /\left(0.3 \mathrm{La}_{2} \mathrm{O}_{3}-0.7 \mathrm{CeO}_{2}\right) ;\left(\right.$ g) $\mathrm{LaNiO}_{3}$.

Moreover, the samples with nominal formula $\mathrm{CeNiO}_{3}, \mathrm{La}_{0.3} \mathrm{Ce}_{0.7} \mathrm{NiO}_{3}$, and $10 \mathrm{wt} \%$ $\mathrm{Ni} /\left(0.3 \mathrm{La}_{2} \mathrm{O}_{3}-0.7 \mathrm{CeO}_{2}\right)$ showed the main reflection peaks of $\mathrm{CeO}_{2}$ and $\mathrm{NiO}$, the latter hardly visible in the impregnated sample, due to the lower concentration. On the contrary, $\mathrm{LaNiO}_{3}$ and the same sample partially substituted with $\mathrm{Sr}$ revealed the typical reflections of the $\mathrm{LaNiO}_{3}$ phase. All the samples showed quite broad and poorly intense reflections, as a measure of the low crystal size and nanostructuring, typical of the FP synthesis method.

Temperature programmed reduction (TPR, Figure 5) was carried out on the samples to determine the temperature range for the activation of the active phase, metallic $\mathrm{Ni}$, in some samples available in the form of mixed oxide, and in other cases as $\mathrm{NiO}$ or as impregnated 
precursor salt. As already widely discussed elsewhere, the reduction temperature for the same oxide can be correlated to its dispersion and to the strength of the interaction with the support. The higher the reduction temperature, the stronger such interaction and typically the higher the metal oxide dispersion. Sharp reduction patterns also testify to the presence of homogeneous types of sites.
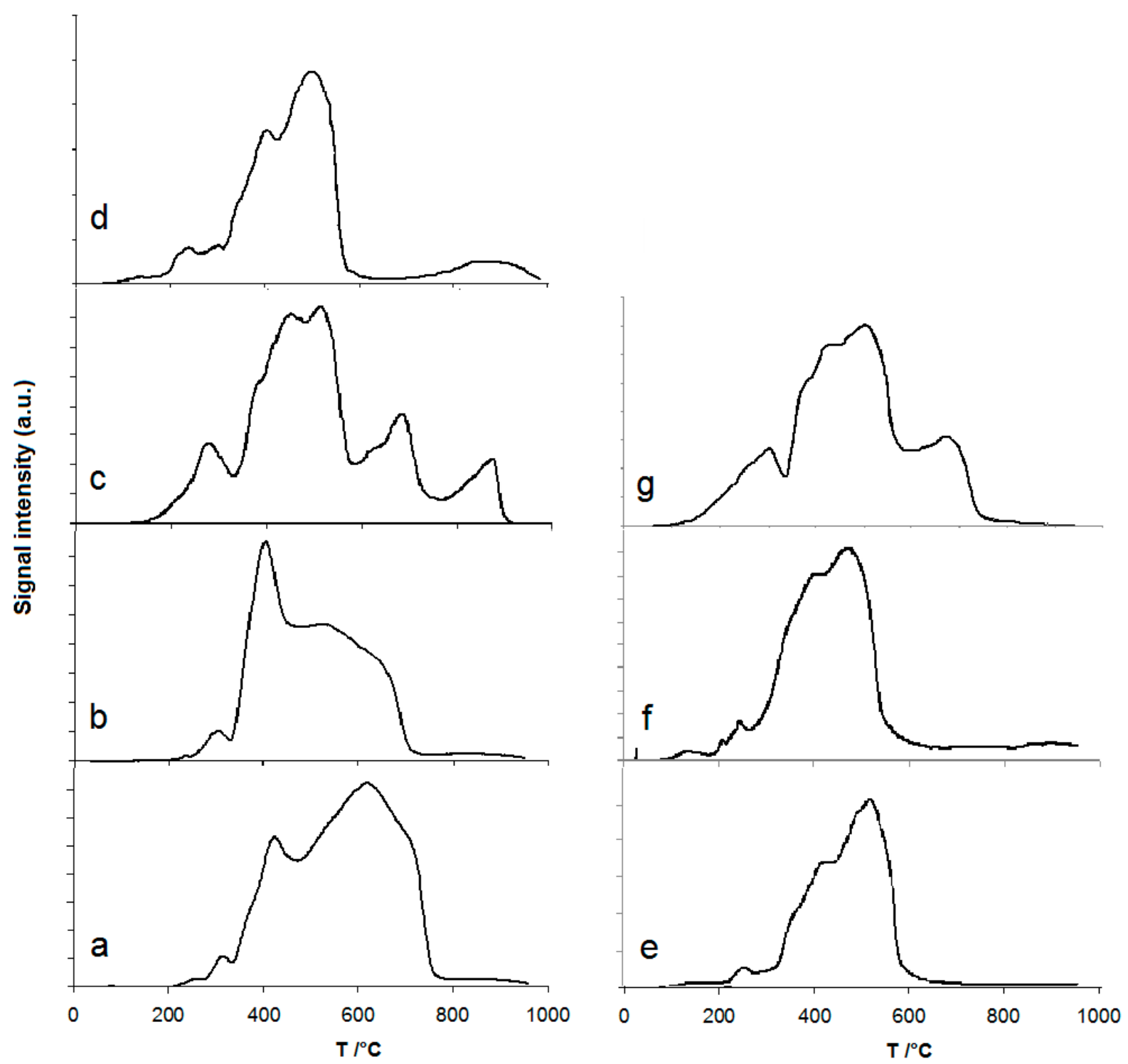

Figure 5. Temperature programmed reduction (TPR) patterns of the FP-prepared catalysts. Signal intensity in arbitrary units. (a) $\mathrm{La}_{0.3} \mathrm{Zr}_{0.7} \mathrm{NiO}_{3} ;$ (b) $10 \mathrm{wt} \% \mathrm{Ni} /\left(0.3 \mathrm{La}_{2} \mathrm{O}_{3}-0.7 \mathrm{ZrO}_{2}\right)$; (c) $\mathrm{La}_{0.8} \mathrm{Sr}_{0.2} \mathrm{NiO}_{3} ;$ (d) $\mathrm{CeNiO}_{3} ;(\mathbf{e}) \mathrm{La}_{0.3} \mathrm{Ce}_{0.7} \mathrm{NiO}_{3} ;(\mathbf{f}) 10 \mathrm{wt} \%$ $\mathrm{Ni} /\left(0.3 \mathrm{La}_{2} \mathrm{O}_{3}-0.7 \mathrm{CeO}_{2}\right) ;\left(\right.$ g) $\mathrm{LaNiO}_{3}$.

In the present samples $\mathrm{NiO}$ reduced between 200 and $600{ }^{\circ} \mathrm{C}$, with broader reduction peaks when the supporting oxide was based on $\mathrm{La} / \mathrm{Zr}$ than when supported over $\mathrm{La} / \mathrm{Ce}$ (pattern $a$ compared with $e$ and pattern $b$ compared with $f$ ). A reduction peak at high temperature (ca. $800{ }^{\circ} \mathrm{C}$ ) appeared for $\mathrm{CeNiO}_{3}$ due to the partial reduction of the $\mathrm{CeO}_{2}$ support, while $\mathrm{ZrO}_{2}$ and $\mathrm{La}_{2} \mathrm{O}_{3}$ did not reduce under the present conditions.

The highest was the amount of $\mathrm{NiO}$ included as mixed phase into the support oxide, determined by $\mathrm{XRD}$, the highest was the average reduction temperature of $\mathrm{NiO}$. For instance, for the samples $\mathrm{La}_{1-x} \mathrm{Sr}_{x} \mathrm{NiO}_{3}$, three or four reduction peaks were present, with the highest temperature ones above $600{ }^{\circ} \mathrm{C}$. For $\mathrm{LaNiO}_{3}$, curve $g$, differently reducible $\mathrm{Ni}^{2+}$ 
species were present and the predominant ones were reducing between 300 and $600{ }^{\circ} \mathrm{C}$. By contrast, for sample $\mathrm{La}_{0.3} \mathrm{Zr}_{0.7} \mathrm{NiO}_{3}$ (curve $a$ ), the highest intensity peak appeared between 500 and $750{ }^{\circ} \mathrm{C}$, underlining the presence of a higher concentration of less reducible $\mathrm{Ni}^{2+}$.

Furthermore, curves $d$ and $e$, corresponding to similar Ce-containing samples, with or without $\mathrm{La}_{2} \mathrm{O}_{3}$, were practically overlapping, but with a very slight shift towards higher temperatures for the sample containing lanthanum oxide.

The direct incorporation of $\mathrm{Ni}$ during the synthesis led to a generaly higher reduction temperature (curves $a$ vs. $b$ for La-Zr and $e$ vs. $f$ for La-Ce) with respect to the samples obtained by impregnation of $\mathrm{Ni}$, though maintaining a similar reduction profile.

Summing up, the highest $\mathrm{Ni}$ dispersion and strength of interaction with the support is shown for the $\mathrm{La}_{1-x} \mathrm{Sr}_{x} \mathrm{NiO}_{3}$ and $\mathrm{La}-\mathrm{Zr}-\mathrm{Ni}$ samples, especially when the latter are prepared as mixed oxides with $\mathrm{Ni}$ incorporation during the support synthesis. This, in princible, would ensure higher thermal resistance towards sintering and higher robustness towards the coking features. Indeed, coking implies carbides' accumulation in the metal and overall leads to the formation of $C$ nanotubes, as widely discussed in the literature $[38,47,48]$. This mechanism is inhibited when $\mathrm{Ni}$ is well dispersed and strongly interacting with the support.

\subsection{Catalytic Activity}

The catalysts were tested for the steam reforming of glycerol, focusing mainly on the characterisation of the gas phase products and on the stability with time-on-stream.

Reactant conversions were referred to glycerol, i.e., the limiting reactant, calculated as in Equation (1), where in represent the molar florates entering (in) or outflowing (out) the reactor. The selectivity to each detected product (Equation (2)) was calculated with respect to the reacted glycerol, taking into account the stoichiometric coefficient $v_{i}$ while the yield (Equation (3)) is given by the product of conversion and selectivity.

$$
\begin{gathered}
\text { Glycerol conversion }(\%)=\frac{\left(n_{\text {glycerol }}\right)_{\text {in }}-\left(n_{\text {glycerol }}\right)_{\text {out }}}{\left(n_{\text {glycerol }}\right)_{\text {in }}} \times 100 \\
\text { Selectivity } \left._{i} \%\right)=\frac{\left(n_{i}\right)_{\text {out }}}{v_{i}\left[\left(n_{\text {glycerol }}\right)_{\text {in }}-\left(n_{\text {glycerol }}\right)_{\text {out }}\right]} \times 100 \\
\text { Yield }_{i}(\%)=\frac{\text { Glycerol conversion }(\%) \times \text { Selectivity }_{i}(\%)}{100}=\frac{\left(n_{i}\right)_{\text {out }}}{v_{i}\left(n_{\text {glycerol }}\right)_{\text {in }}} \times 100
\end{gathered}
$$

The results of catalytic activity testing at $6500^{\circ} \mathrm{C}$ are compared for all samples reporting glycerol conversion (Figure 6), hydrogen yield (Figure 7), and selectivity to $\mathrm{CH}_{4}$ (Figure 8). Only a single temperature was considered, on the basis of previous investigations $[49,50]$. The latter is a common byproduct, which is hardly reformable except at a very high temperature $\left(750-800^{\circ} \mathrm{C}\right)$ over $\mathrm{Ni}$ catalysts, and decreases hydrogen yield. An example of the selectivity patterns for two interesting samples is also reported in Figure 9. 


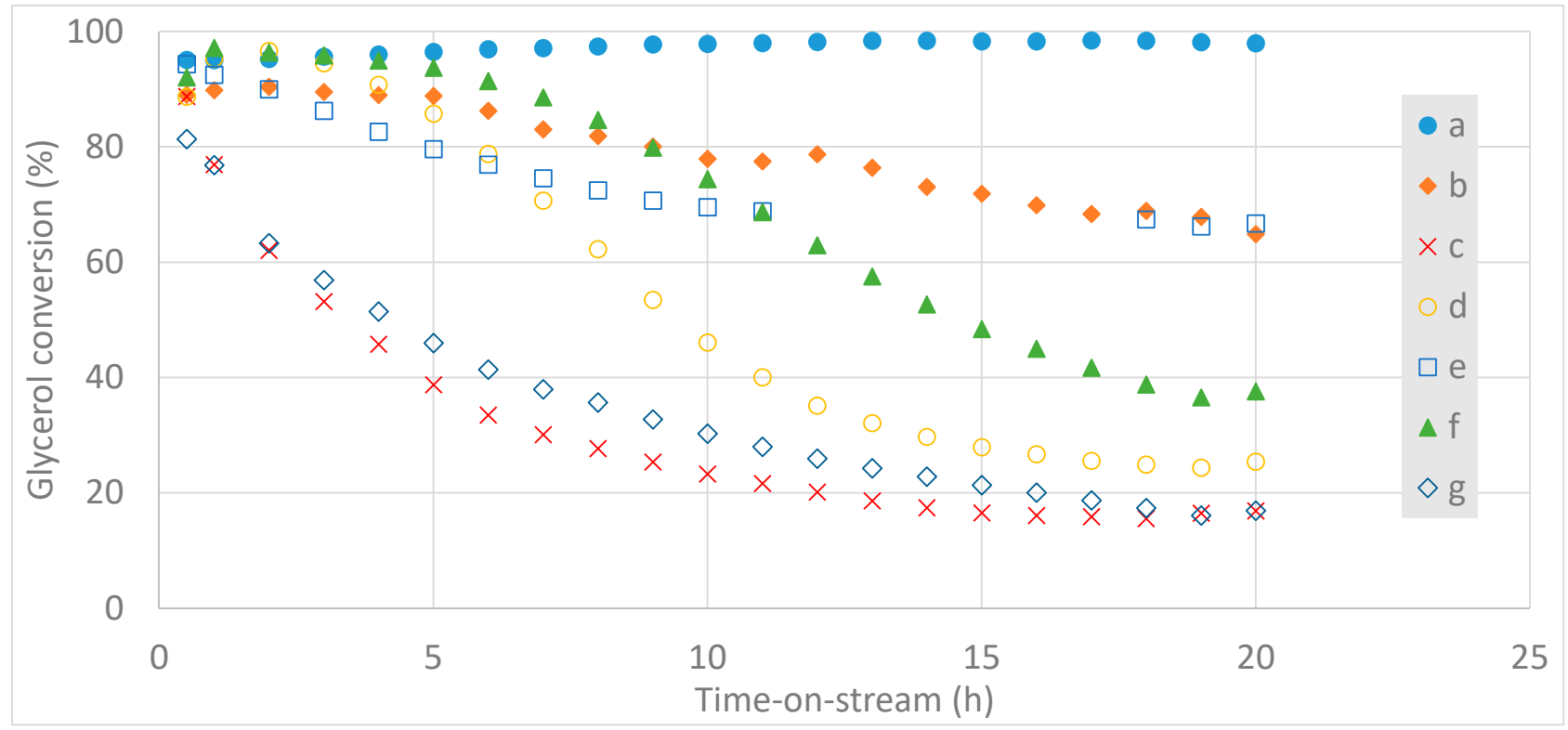

Figure 6. Glycerol conversion at $650{ }^{\circ} \mathrm{C}$, feed $10 \mathrm{wt} \%$ glycerol in water: (a) $\mathrm{La}_{0.3} \mathrm{Zr}_{0.7} \mathrm{NiO}_{3} ;$ (b) $10 \mathrm{wt} \% \mathrm{Ni} /\left(0.3 \mathrm{La} 2 \mathrm{O}_{3}-\right.$ $\left.0.7 \mathrm{ZrO}_{2}\right) ;(\mathbf{c}) \mathrm{La}_{0.8} \mathrm{Sr}_{0.2} \mathrm{NiO}_{3} ;$ (d) $\mathrm{CeNiO}_{3} ;$ (e) $\mathrm{La}_{0.3} \mathrm{Ce}_{0.7} \mathrm{NiO}_{3} ;$ (f) $10 \mathrm{wt} \% \mathrm{Ni} /\left(0.3 \mathrm{La}_{2} \mathrm{O}_{3}-0.7 \mathrm{CeO}_{2}\right) ;(\mathrm{g}) \mathrm{LaNiO}_{3}$.

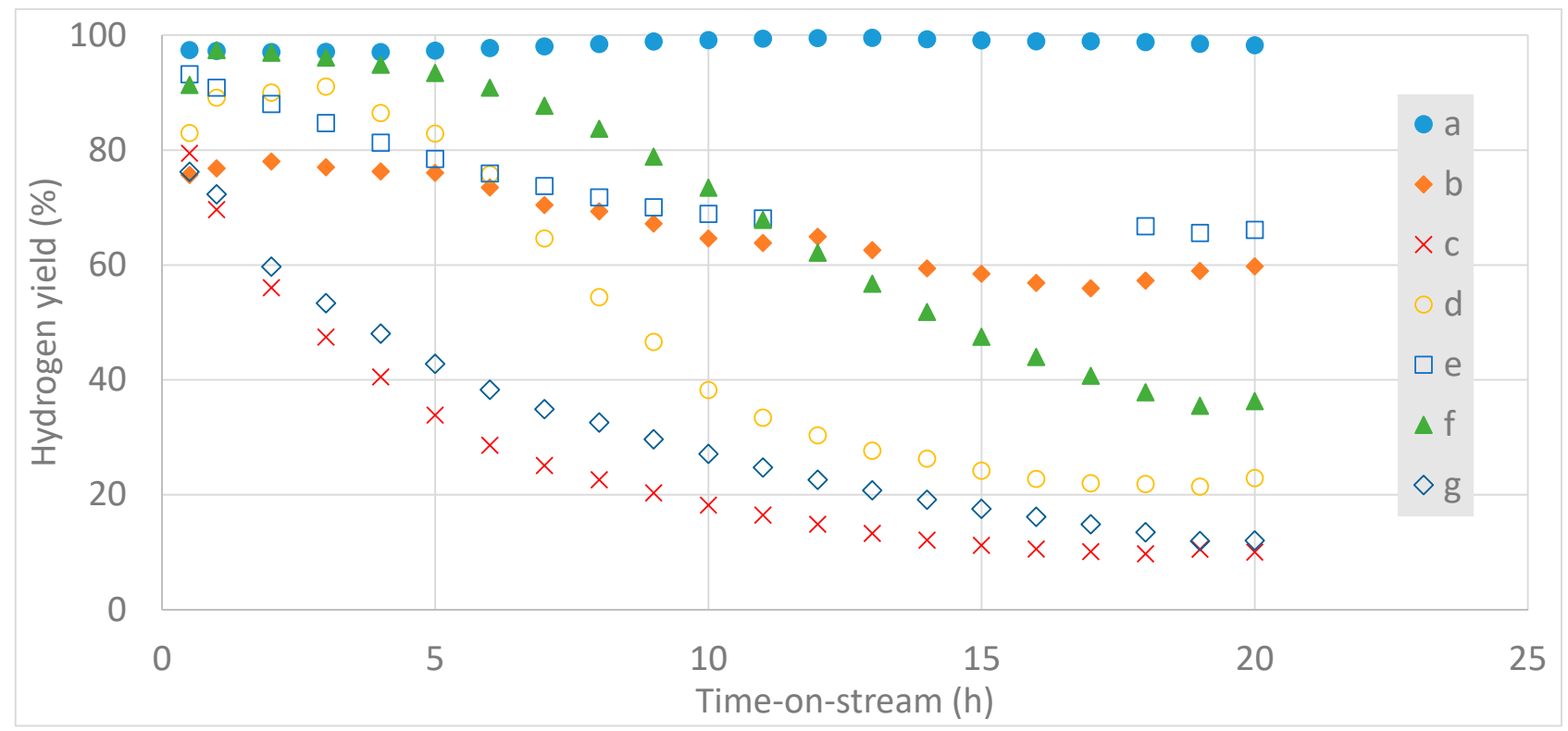

Figure 7. Hydrogen yield at $650{ }^{\circ} \mathrm{C}$, feed $10 \mathrm{wt} \%$ glycerol in water. (a) $\mathrm{La}_{0.3} \mathrm{Zr}_{0.7} \mathrm{NiO}_{3} ;$ (b) $10 \mathrm{wt} \% \mathrm{Ni} /\left(0.3 \mathrm{La}_{2} \mathrm{O}_{3}-0.7 \mathrm{ZrO}\right)$; (c) $\mathrm{La}_{0.8} \mathrm{Sr}_{0.2} \mathrm{NiO}_{3} ;$ (d) $\mathrm{CeNiO}_{3} ;$ (e) $\mathrm{La}_{0.3} \mathrm{Ce}_{0.7} \mathrm{NiO}_{3} ;$ (f) $10 \mathrm{wt} \% \mathrm{Ni} /\left(0.3 \mathrm{La}_{2} \mathrm{O}_{3}-0.7 \mathrm{CeO}_{2}\right) ;\left(\right.$ g) $\mathrm{LaNiO}_{3}$. 


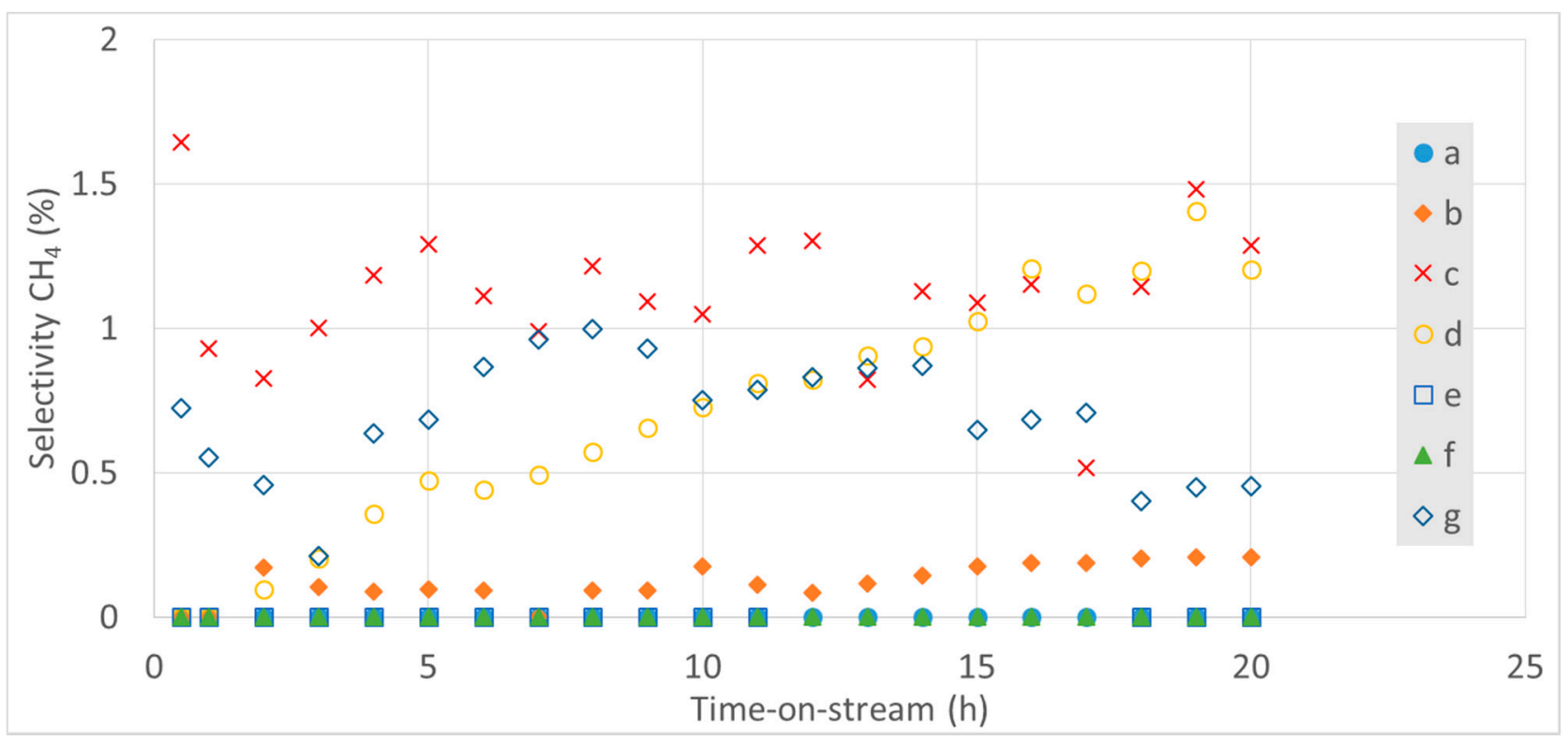

Figure 8. Selectivity to $\mathrm{CH}_{4}$ at $650{ }^{\circ} \mathrm{C}$, feed $10 \mathrm{wt} \%$ glycerol in water. (a) $\mathrm{La}_{0.3} \mathrm{Zr}_{0.7} \mathrm{NiO}_{3} ;$ (b) $10 \mathrm{wt} \% \mathrm{Ni} /\left(0.3 \mathrm{La}_{2} \mathrm{O}_{3}-0.7 \mathrm{ZrO}\right)_{2}$; (c) $\mathrm{La}_{0.8} \mathrm{Sr}_{0.2} \mathrm{NiO}_{3} ;$ (d) $\mathrm{CeNiO}_{3} ;$ (e) $\mathrm{La}_{0.3} \mathrm{Ce}_{0.7} \mathrm{NiO}_{3} ;$ (f) $10 \mathrm{wt} \% \mathrm{Ni} /\left(0.3 \mathrm{La}_{2} \mathrm{O}_{3}-0.7 \mathrm{CeO}_{2}\right) ;\left(\right.$ g) $\mathrm{LaNiO}_{3}$.

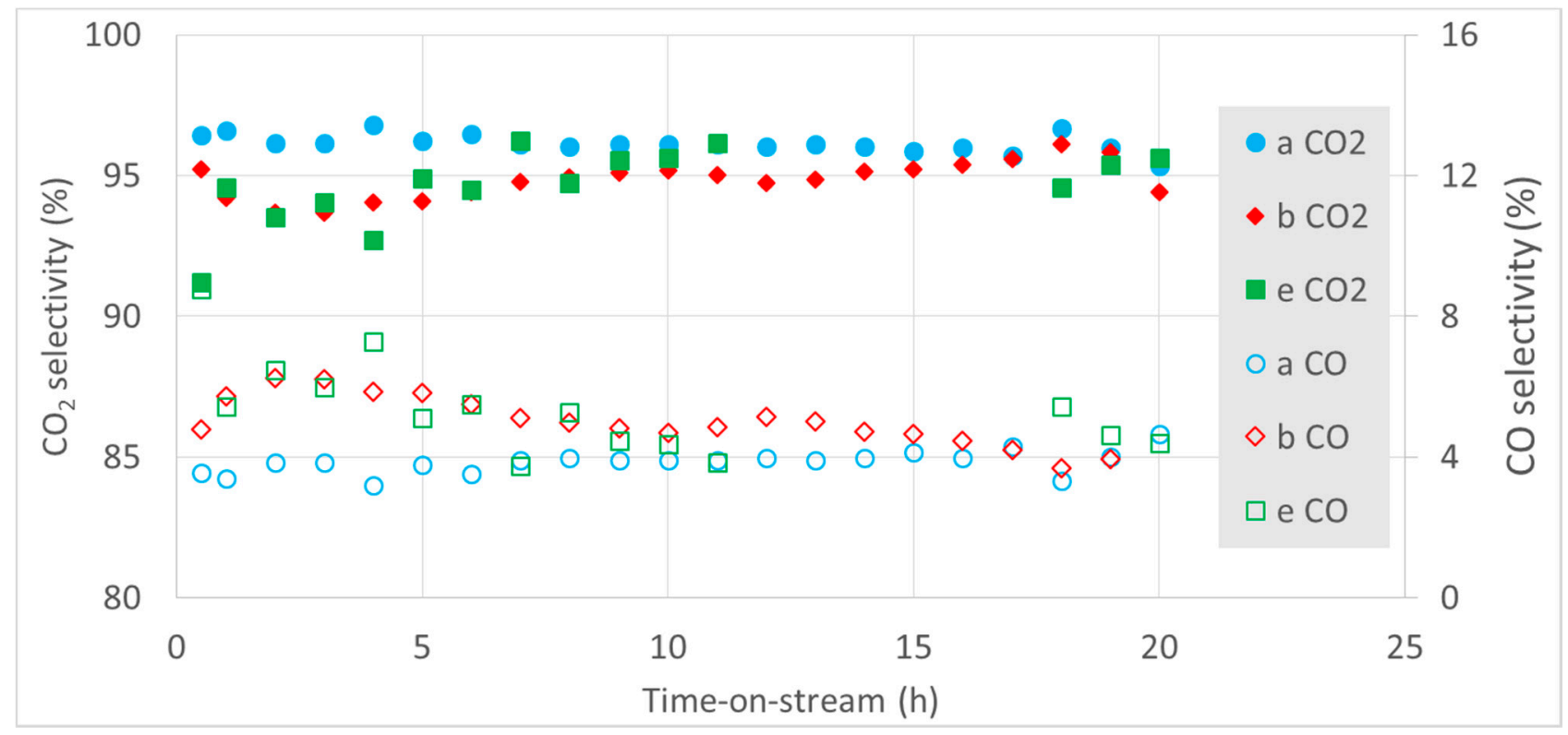

Figure 9. Selectivity to $\mathrm{CO}$ (right) and $\mathrm{CO}_{2}$ (left) at $650{ }^{\circ} \mathrm{C}$, feed $10 \mathrm{wt} \%$ glycerol in water. (a) $\mathrm{La}_{0.3} \mathrm{Zr}_{0.7} \mathrm{NiO}_{3} ;(\mathbf{b}) 10 \mathrm{wt} \%$ $\mathrm{Ni} /\left(0.3 \mathrm{La}_{2} \mathrm{O}_{3}-0.7 \mathrm{ZrO}_{2}\right) ;(\mathbf{e}) \mathrm{La}_{0.3} \mathrm{Ce}_{0.7} \mathrm{NiO}_{3}$.

The selectivity to hydrogen was close to $100 \%$, leading to a yield pattern very similar to the conversion one (Figures 6 and 7). This indicates the absence of significant amounts of hydrogen containing byproducts. The carbon containing products were mainly $\mathrm{CO}_{2}$ (predominant) and $\mathrm{CO}$, with a limited amount of $\mathrm{CH}_{4}$ for some catalysts only.

The less active samples were $\mathrm{La}_{1-x} \mathrm{Sr}_{x} \mathrm{NiO}_{3}$, which revealed initial glycerol conversion between 80 and $90 \%$, but very rapidly deactivated to ca. $20 \%$ residual conversion after only $20 \mathrm{~h}$ on stream. $\mathrm{CeNiO}_{3}$ also demonstrated insufficient stability. The mixed formulation $\mathrm{La}_{0.3} \mathrm{Ce}_{0.7} \mathrm{NiO}_{3}$ showed higher initial conversion and a little better stability with timeon-stream, though still unsatisfactory. Worse long-term results were obtained with $\mathrm{Ni}$ impregnated on the $\mathrm{La}_{2} \mathrm{O}_{3}-\mathrm{CeO}_{2}$ mixed support compared to when it was added with the 
other precursors in mixed oxide synthesis The latter sample reached a ca. $65 \%$ plateau conversion with respect to ca. $40 \%$ for the impregnated sample.

The best results in terms of both initial conversion and, above all, optimal resistance with time-on-stream were achieved with the $\mathrm{La}_{0.3} \mathrm{Zr}_{0.7} \mathrm{NiO}_{3}$ sample. Also for this system, the introduction of nickel by impregnation worsened the catalytic performance, in terms of glycerol conversion.

A similar profile is evident for hydrogen yield, given its selectivity is almost quantitative in the gas phase products. Some methane may be present and incompletely reformed under the selected reaction conditions (Figure 8). Methane can form through direct decomposition of glycerol, but more likely by methanation of $\mathrm{CO}(\mathrm{R} 2)$ and $\mathrm{CO}_{2}(\mathrm{R} 3)$, as $\mathrm{Ni}$ is a well-known methanation catalyst [51].

$$
\begin{gathered}
\mathrm{CO}+3 \mathrm{H}_{2} \leftrightarrows \mathrm{CH}_{4}+\mathrm{H}_{2} \mathrm{O} \\
\mathrm{CO}_{2}+4 \mathrm{H}_{2} \leftrightarrows \mathrm{CH}_{4}+2 \mathrm{H}_{2} \mathrm{O}
\end{gathered}
$$

Moreover, in this case, worse performance is exhibited by the $\mathrm{La}_{1-x} \mathrm{Sr}_{x} \mathrm{NiO}_{3}$ samples, leading to ca. $1 \%$ selectivity, while $\mathrm{CeNiO}_{3}$ gave rise to a steadily increasing methane selectivity, possibly meaning a progressive deactivation of the active phase, less able to complete the further conversion of this byproduct. Again, the best performing sample was the $\mathrm{La}_{0.3} \mathrm{Zr}_{0.7} \mathrm{NiO}_{3}$, showing nil selectivity to methane for the whole duration of the test.

The trends of $\mathrm{CO}$ and $\mathrm{CO}_{2}$ selectivities are reported in Figure 9 for some of the best performing samples. The predominant product was $\mathrm{CO}_{2}$, with selectivity always higher than $90 \%$, while CO ranged below $10 \%$. This is a positive feature as further hydrogen purification is carried out to remove $\mathrm{CO}$ and its limited selectivity implies easier removal thorugh water gas shift reaction or pressure swing adsorption. Moreover, in this case, perfectly stable data were attained for sample $\mathrm{La}_{0.3} \mathrm{Zr}_{0.7} \mathrm{NiO}_{3}$, while a slightly decreasing selectivity to $\mathrm{CO}$ with time-on-stream is shown by the other two samples.

The two most critical features identified for catalyst deactivation are, operating at high temperature, the metal sintering, and the deposition of coke. The presence of a mixed oxide precursor phase promotes a greater dispersion of $\mathrm{Ni}$ and a high interaction with the support. Both these features should ensure suitable resistance to sintering. On the other hand, coking is related to different aspects. In this work, support acidity, catalysing the formation of olefins and their olygomers, was tuned by selecting intrinsically basic support $\left(\mathrm{La}_{2} \mathrm{O}_{3}\right.$, possibly added with $\left.\mathrm{Sr}\right)$. Given its quite low melting temperature, it was mixed with $\mathrm{ZrO}_{2}$, a high melting point non-reducible oxide, whose acid features are in turn limited by the presence of $\mathrm{La}_{2} \mathrm{O}_{3}$. On the other side, $\mathrm{CeO}_{2}$ was used as support characterised by high oxygen mobility at the reaction temperature, in principle helping to prevent coke accumulation by oxidation of the forming nuclei of coke.

The $\mathrm{CO}$ disproportion reaction is mainly responsible for the formation of $\mathrm{C}$ deposits, while the condensation of hydrocarbons, e.g., olefins, due to acidity of the support (or Lewis acidity due to the active metal itself), could lead to coke species with a different $\mathrm{C} / \mathrm{H}$ ratio. The different coke formation mechanisms are sketched in Figure 10, considering the pathway from $\mathrm{CO}$ and from hydrocarbons' condensation [52].

Overall, different $C$ species are expected on the catalyst surface, with specific reference to Ni containing ones: (i) adsorbed, atomic surface carbide forming between 200 and $400{ }^{\circ} \mathrm{C}$ $\left(\mathrm{C}_{\alpha}\right)$; (ii) polymeric, amorphous films, or filaments, forming between 250 and $500{ }^{\circ} \mathrm{C}\left(\mathrm{C}_{\beta}\right)$; (iii) $\mathrm{C}$ filaments and nanotubes, forming between 300 and $1000{ }^{\circ} \mathrm{C}\left(\mathrm{C}_{\mathrm{v}}\right)$; (iv) bulk NiC, forming between 150 and $250^{\circ} \mathrm{C}\left(\mathrm{C}_{\gamma}\right)$; and (v) graphitic platelets or films, forming between 500 and $550{ }^{\circ} \mathrm{C}\left(\mathrm{C}_{\mathrm{C}}\right)$. The different species form preferably in the indicated temperature ranges and only some metals are able to form stable carbides and nanotubes/whiskers, among which $\mathrm{Ni}$ is one of the most active. The different $\mathrm{C}$ species are also characterised by different stability in the reaction environment, as they can react with steam and $\mathrm{H}_{2}$ to form $\mathrm{CO}$ and $\mathrm{CH}_{4}$. For instance, $\mathrm{C}_{\alpha}$ reacts with $\mathrm{H}_{2}$ at ca. $200{ }^{\circ} \mathrm{C}, \mathrm{C}_{\beta}$ at $400{ }^{\circ} \mathrm{C}$, and $\mathrm{C}_{\mathrm{v}}$ 
between 400 and $600{ }^{\circ} \mathrm{C}$. On the contrary, graphitic carbon reacts only at a much higher temperature, between 550 and $850{ }^{\circ} \mathrm{C}$, allowing it to accumulate over the catalyst.
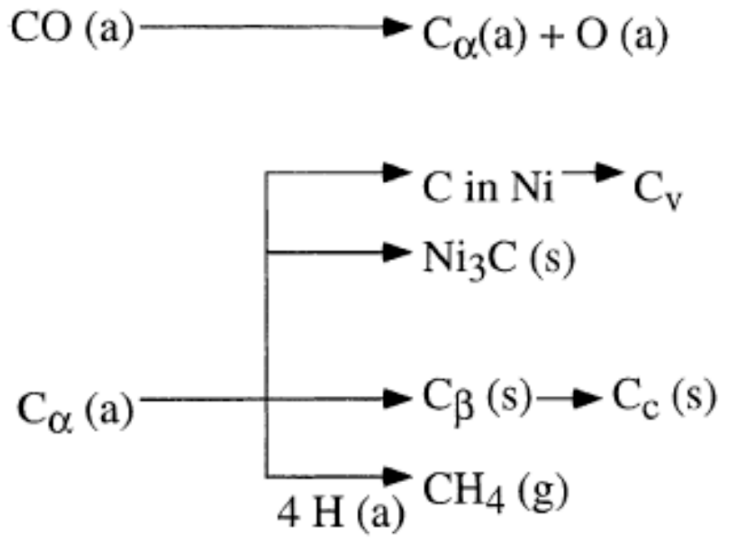

(a)

(Hydrocarbon)

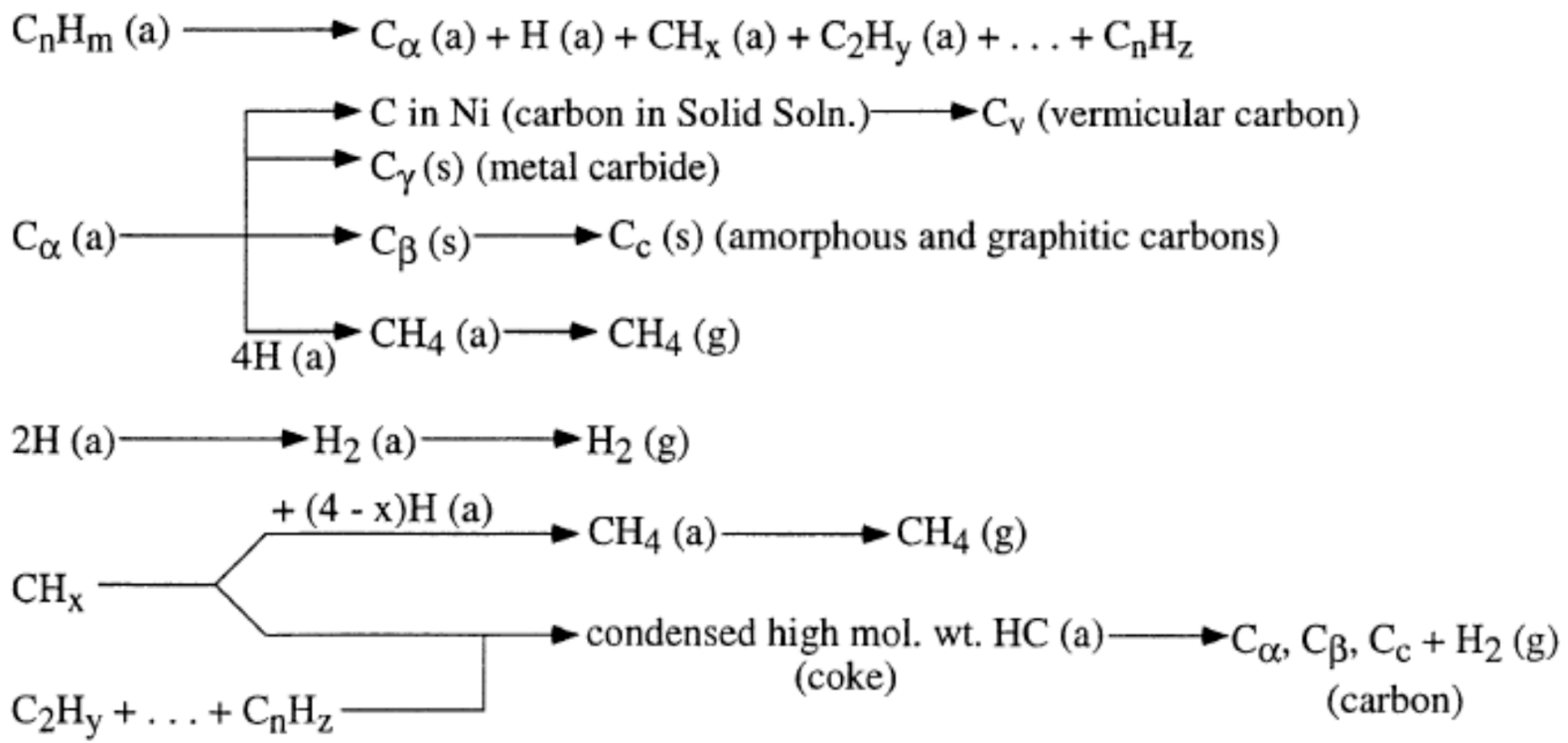

(b)

Figure 10. Coking mechanisms. (a) Formation, transformation, and gasification of carbon on nickel. (b) Formation and transformation of coke on metal surfaces ( $\mathrm{a}, \mathrm{g}$ and s refer to adsorbed, gaseous, and solid states, respectively). Reproduced with kind permission of Elsevier from [52].

TGA in air was carried out by heating up to $1000{ }^{\circ} \mathrm{C}$ to determine the possible weight loss due to the combustion of C-containing species deposed over the catalyst surface; Table 2. The temperature range of $C$ oxidation is also correlated with the stability of the coke, and thus allows one to formulate hypotheses on its nature. 
Table 2. Results of TGA. $\Delta w$ t represents the normalised weight loss.

\begin{tabular}{|c|c|c|c|c|c|c|c|c|c|c|}
\hline Sample & $\begin{array}{l}\Delta w t \\
(\%)\end{array}$ & $\mathbf{T}^{\circ} \mathbf{C}$ & $\begin{array}{l}\Delta w t \\
(\%)\end{array}$ & $\mathbf{T}^{\circ} \mathbf{C}$ & $\begin{array}{l}\Delta w t \\
(\%)\end{array}$ & $\mathbf{T}^{\circ} \mathbf{C}$ & $\begin{array}{l}\Delta w t \\
(\%)\end{array}$ & $\mathbf{T}^{\circ} \mathbf{C}$ & $\begin{array}{l}\Delta w t \\
(\%)\end{array}$ & $\mathbf{T}^{\circ} \mathbf{C}$ \\
\hline $\mathrm{La}_{0.3} \mathrm{Zr}_{0.7} \mathrm{NiO}_{3}$ & 5.7 & $100-400$ & -1.4 & $500-650$ & & & & & & \\
\hline $\begin{array}{c}10 \mathrm{wt} \% \\
\mathrm{Ni} /\left(0.3 \mathrm{La}_{2} \mathrm{O}_{3}-\right. \\
\left.0.7 \mathrm{ZrO}_{2}\right)\end{array}$ & 1.0 & $200-400$ & -2.3 & $400-600$ & & & & & & \\
\hline $\mathrm{La}_{0.8} \mathrm{Sr}_{0.2} \mathrm{NiO}_{3}$ & -1.5 & $250-300$ & 4.9 & $300-500$ & -2.5 & $650-700$ & -1.5 & $700-750$ & -1.5 & $800-850$ \\
\hline $\mathrm{CeNiO}_{3}$ & 4.9 & $200-400$ & & & & & & & & \\
\hline $\mathrm{La}_{0.3} \mathrm{Ce}_{0.7} \mathrm{NiO}_{3}$ & 5 & $100-400$ & & & & & & & & \\
\hline $\begin{array}{c}10 \mathrm{wt} \% \\
\mathrm{Ni} /\left(0.3 \mathrm{La}_{2} \mathrm{O}_{3}-\right. \\
\left.0.7 \mathrm{CeO}_{2}\right)\end{array}$ & 1.6 & $150-400$ & & & & & & & & \\
\hline $\mathrm{LaNiO}_{3}$ & -0.6 & $260-310$ & 3.9 & $310-600$ & -1.5 & $600-750$ & -0.5 & $850-900$ & -0.3 & 950-1000 \\
\hline
\end{tabular}

All the samples showed a positive peak (weight increase) due to the oxidation of reduced $\mathrm{Ni}$. Indeed, it was roughly proportional to $\mathrm{Ni}$ content. $\mathrm{CeO}_{2}$ containing samples did not reveal any weight loss attributed to coke combustion,. supporting the hypothesis that the widely known oxygen mobility and buffering properties of this oxide may be an effective prevention of coke accumulation over the catalyst. The $\mathrm{La}_{1-x} \mathrm{Sr}_{x} \mathrm{NiO}_{3}$ samples showed many different negative peaks, appearing atvery different temperature ranges. Being composed of non reducible oxides (except $\mathrm{NiO}$ ), the high temperature peak cannot be attributed to oxygen loss from the support. The lowest temperature weight loss can be ascribed to adsorbed, unstructured C, while the high temperature ones to more structured $\mathrm{C}$, such as the whiskers or graphitic one. By looking at the catalytic activity tests, these were the samples more rapidly deactivating, which indeed suggests the fast coke accumulation over the Ni surface and possibly over the support. The latter is also involved in water activation, so the coverage of its surface by coke hinders this part of the reaction mechanism.

On the contrary, sample $\mathrm{La}_{0.3} \mathrm{Zr}_{0.7} \mathrm{NiO}_{3}$ showed one weight loss feature, quite limited $(-1.4 \mathrm{wt} \%)$ occurring at a relatively high temperature.

This result, together with the exceptional stability of this sample during the test, leads to exclude the accumulation of coke on $\mathrm{Ni}$ or the formation of nanotubes. It is possible that the TGA peak may correspond to some coke accumulated over some residual acidic $\mathrm{ZrO}_{2}$ sites, which irreversibly deactivate. Slightly greater weight loss and lower oxidation temperature were obtained for the $10 \mathrm{wt} \% \mathrm{Ni} /\left(0.3 \mathrm{La}_{2} \mathrm{O}_{3}-0.7 \mathrm{ZrO}_{2}\right)$ sample. This can be ascribed to Ni coking (possibly with formation of nanotubes) to explain the progressive catalyst deactivation observed in Figure 6.

By comparing these results with the performance of the catalyst, taking into account the results of the structural characterization, it can be confirmed that the greater dispersion of Ni obtained by adding Ni during FP synthesis is effective in increasing its dispersion (lower reducibility) and thermal stability towards the sintering

Almost $100 \%$ conversion of glycerol was similarly reported for $15 \% \mathrm{Ni} / \mathrm{La}_{2} \mathrm{O}_{3}-\mathrm{ZrO}_{2}$ and $12 \% \mathrm{Ni} / \mathrm{CeO}_{2}-\mathrm{ZrO}_{2}$, tested under similar conditions [17]. However, most catalytic systems showed a decreasing conversion trend with time-on-stream, underlying deactivation issues mainly related to coking. Perovskite-based catalysts were also tested for this application. For instance, $\mathrm{LaNiO}_{3}$ tested at $650{ }^{\circ} \mathrm{C}$ led to 58 to $72 \%$ conversion, depending on the preparation method and conditions [53,54]. Moreover, when the Ni precursor was in the form of hydrotalcite, better performance and most of all stability was reported, attributing deactivation by coking to sintering of the Ni nanoparticles [17], in line with recent findings.

To sum up, the steam reforming of glycerol can be a valuable option to valorise this byproduct of biodiesel production in the same commercial compartment, i.e., the energy 
sector, better matching the increasing production volume. Despite the promising preliminary results in terms of activity, two main issues needed solutions: (i) the employment of noble metals in most of the best performing catalyst formulations; (ii) insufficient catalyst stability. Therefore, in the present work, we successfully focused on the application of $\mathrm{Ni}$ as active phase, which was already demonstrated to be active for many different substrates and is less expensive than noble metals. As for the second point, the key problem to be addressed is catalyst coking, which can be ascribed to two main issues-the acidity of the catalyst and the possible formation of carbon nanotubes due to the subsurface accumulation of carbides at the $\mathrm{Ni}$ /support interphase.

To cope with these pointswe have applied different strategies. On one hand, we have confirmed that the Ni dispersion and the interaction with the support is a good strategy to limit the growth of carbon over the metal particle. Therefore, we have directly incorporated $\mathrm{Ni}$ in mixed oxide formulations with the precursors of the support. This improved the $\mathrm{Ni}$ dispersion after reduction and tightened the strength of the interaction with the support. These materials were compared with samples obtained by wet impregnation of Ni over the support. TPR was selected as a tool to interpret the strength of the metal-support interaction, i.e., the higher the reduction temperature of $\mathrm{Ni}$, the stronger the metal-support interaction and/or the higher the metal dispersion (in principle, improving the resistance to both sintering and coking).

Finally, the flame pyrolysis technique adopted for the oxides synthesis was able to impart sufficient thermal resistance and to favor the Ni dispersion inside the precursor oxide material. The main challenge of this research work, the adopted strategies, and the results are summed up in Scheme 1.

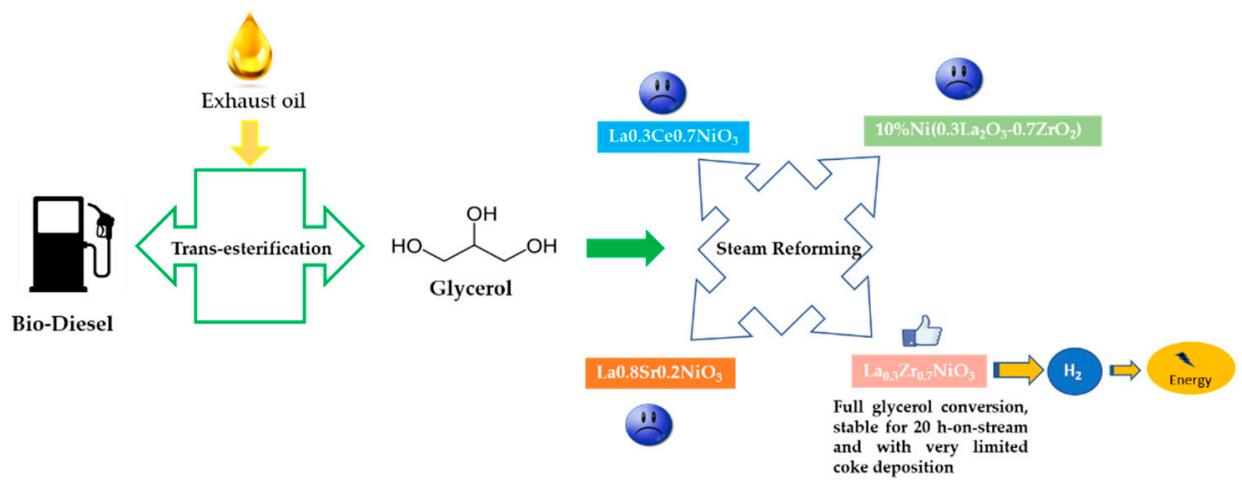

Scheme 1. Main challenge and outcomes.

\section{Conclusions}

The steam reforming of glycerol was studied as a mean to valorise a byproduct of biodiesel production for the production of hydrogen. The catalysts were designed based on $\mathrm{Ni}$ as active phase, supported over basic or oxygen conducting oxides. In order to favour a strong metal-support interaction, which ensures good metal dispersion and stability to sintering, mixed oxide formulations were designed with varying nominal formulation. A really stoichiometric mixed oxide was achieved only in the case of $\mathrm{La}_{1-x} \mathrm{Sr}_{x} \mathrm{NiO}_{3}$ catalysts, which, however, were revealed to be very poorly stable during activity testing and prone to coking. On the contrary, formulations containing $\mathrm{CeO}_{2}$ were not really active, but they did not accumulate coke during testing. The incorporation of Ni during the FP synthesis, even in a high amount, was beneficial to improve its dispersion and interaction strength with the support, testified by lower Ni reducibility. By contrast, the addition of Ni by impregnation led to worse performing samples, less active and more prone to coking.

Overall, the best results were obtained with catalyst $\mathrm{La}_{0.3} \mathrm{Zr}_{0.7} \mathrm{NiO}_{3}$, which led to full glycerol conversion, stable for $20 \mathrm{~h}$ on stream and with very limited coke deposition, likely covering the not-titrated most acidic sites of $\mathrm{ZrO}_{2}$ that, once deactivated, were completely ruled out. 
Author Contributions: Conceptualization, A.D.M.; Data curation, F.C. and V.D.S.; Methodology, S.E. and V.D.S.; Supervision, A.D.M. and G.R.; Writing—original draft, I.R.; Writing-review \& editing, S.E., G.R. and I.R. All authors have read and agreed to the published version of the manuscript.

Funding: This research received no external funding.

Data Availability Statement: Data is contained within the article or supplementary material.

Conflicts of Interest: The authors declare no conflict of interest.

\section{References}

1. Hosseini, S.E.; Wahid, M.A. Hydrogen production from renewable and sustainable energy resources: Promising green energy carrier for clean development. Renew. Sustain. Energy Rev. 2016, 57, 850-866. [CrossRef]

2. Balat, H.; Kirtay, E. Hydrogen from biomass-Present scenario and future prospects. Int. J. Hydrogen Energy 2010, 35, 7416-7426. [CrossRef]

3. Bičáková, O.; Straka, P. Production of hydrogen from renewable resources and its effectiveness. Int. J. Hydrogen Energy 2012, 37, 11563-11578. [CrossRef]

4. Rass-Hansen, J.; Johansson, R.; Møller, M.; Christensen, C.H. Steam reforming of technical bioethanol for hydrogen production. Int. J. Hydrogen Energy 2008, 33, 4547-4554. [CrossRef]

5. Dou, B.; Son, Y.; Wang, C.; Chen, H.; Xu, Y. Hydrogen production from catalytic steam reforming of biodiesel byproduct glycerol: Issues and challenges. Renew. Sustain. Energy Rev. 2014, 30, 950-960. [CrossRef]

6. Top Five Countries for Biofuel Production across the Globe. Available online: https://www.nsenergybusiness.com/features/topbiofuel-production-countries / (accessed on 9 September 2020).

7. Singh, D.; Sharma, D.; Soni, S.; Inda, C.S.; Sharma, S.; Sharma, P.K.; Jhalani, A. A comprehensive review of physicochemical properties, production process, performance and emissions characteristics of 2nd generation biodiesel feedstock: Jatropha curcas. Fuel 2021, 285, 119110. [CrossRef]

8. Abomohra, A.E.-F.; Elsayed, M.; Esakkimuthu, S.; El-Sheekh, M.; Hanelt, D. Potential of fat, oil and grease (FOG) for biodiesel production: A critical review on the recent progress and future perspectives. Prog. Energy Combust. Sci. 2020, 81, 100868. [CrossRef]

9. Chia, W.Y.; Chong, Y.Y.; Chew, K.W.; Vimali, E.; Jayaram, M.; Selvarajoo, A.; Muthuvelu, K.S.; Varalakshmi, P.; Show, P.L.; Arumugasamy, S.K. Outlook on biorefinery potential of palm oil mill effluent for resource recovery. J. Environ. Chem. Eng. 2020, 8, 104519. [CrossRef]

10. Ananthi, V.; Raja, R.; Carvalho, I.S.; Brindhadevi, K.; Ad, P.; Arun, A. A realistic scenario on microalgae based biodiesel production: Third generation biofuel. Fuel 2021, 284, 118965. [CrossRef]

11. Checa, M.; Nogales, S.; Montes, V.; Encinar, J.M. Recent advances in glycerol catalytic valorization: A review. Catalysts 2020, 10, 1279. [CrossRef]

12. Lima, D.S.; Calgaro, C.O.; Perez-Lopez, O.W. Hydrogen production by glycerol steam reforming over Ni based catalysts prepared by different methods. Biomass Bioenergy 2019, 130, 105358. [CrossRef]

13. Yancheshmeh, M.S.; Sahraei, O.A.; Aissaoui, M.; Iliuta, M.C. A novel synthesis of NiAl2O4 spinel from a Ni-Al mixed-metal alkoxide as a highly efficient catalyst for hydrogen production by glycerol steam reforming. Appl. Catal. B Environ. 2020, 265, 118535. [CrossRef]

14. Dahdah, E.; Estephane, J.; Gennequin, C.; Aboukaïs, A.; Abi-Aad, E.; Aouad, S.A. Zirconia supported nickel catalysts for glycerol steam reforming: Effect of zirconia structure on the catalytic performance. Int. J. Hydrogen Energy 2020, 45, 4457-4467. [CrossRef]

15. Charisiou, N.D.; Siakavelas, G.; Tzounis, L.; Dou, B.; Sebastian, V.; Hinder, S.; Baker, M.; Polychronopoulou, K.; Goula, M.A. $\mathrm{Ni} / \mathrm{Y} 2 \mathrm{O} 3-\mathrm{ZrO} 2$ catalyst for hydrogen production through the glycerol steam reforming reaction. Int. J. Hydrogen Energy 2020, 45, 10442-10460. [CrossRef]

16. Veiga, S.; Faccio, R.; Romero, M.; Bussi, J. Utilization of waste crude glycerol for hydrogen production via steam reforming over $\mathrm{Ni}-\mathrm{La}-\mathrm{Zr}$ catalysts. Biomass Bioenergy 2020, 135, 105508. [CrossRef]

17. Saeidabad, N.G.; Noh, Y.S.; Eslami, A.A.; Song, H.-T.; Kim, H.D.; Fazeli, A.; Moon, D.J. A review on catalysts development for steam reforming of biodiesel derived glycerol; Promoters and supports. Catalysts 2020, 10, 910. [CrossRef]

18. Adeniyi, A.G.; Ighalo, J.O. A review of steam reforming of glycerol. Chem. Pap. 2019, 73, 2619-2635. [CrossRef]

19. Bepari, S.; Kuila, D. Steam reforming of methanol, ethanol and glycerol over nickel-based catalysts-A review. Int. J. Hydrogen Energy 2020, 45, 18090-18113. [CrossRef]

20. Buffoni, I.N.; Pompeo, F.; Santori, G.F.; Nichio, N.N. Nickel catalysts applied in steam reforming of glycerol for hydrogen production. Catal. Commun. 2009, 10, 1656-1660. [CrossRef]

21. Esposito, S.; Turco, M.; Bagnasco, G.; Cammarano, C.; Pernice, P. New insight into the preparation of copper/zirconia catalysts by sol-gel method. Appl. Catal. A Gen. 2011, 403, 128-135. [CrossRef]

22. Dell'Agli, G.; Esposito, S.; Mascolo, G.; Mascolo, M.; Pagliuca, C. Films by slurry coating of nanometric YSZ (8mol\% Y2O3) powders synthesized by low-temperature hydrothermal treatment. J. Eur. Ceram. Soc. 2005, 25, 2017-2021. [CrossRef] 
23. Turco, R.; Bonelli, B.; Armandi, M.; Spiridigliozzi, L.; Dell'Agli, G.; Deorsola, F.; Esposito, S.; Di Serio, M.; Deorsol, F. Active and stable ceria-zirconia supported molybdenum oxide catalysts for cyclooctene epoxidation: Effect of the preparation procedure. Catal. Today 2020, 345, 201-212. [CrossRef]

24. Liao, Y.; Van Chi, N.; Ishiguro, N.; Young, A.P.; Tsung, C.; Wu, K.C. Engineering a homogeneous alloy-oxide interface derived from metal-organic frameworks for selective oxidation of 5-hydroxymethylfurfural to 2,5-furandicarboxylic acid. Appl. Ca-talysis B Environ. 2020, 270, 118805. [CrossRef]

25. Konnerth, H.; Matsagar, B.M.; Chen, S.S.; Prechtl, M.H.G.; Shieh, F.; Wu, K.C. Metal-organic framework (MOF)-derived catalysts for fine chemical production. Coord. Chem. Rev. 2020, 416, 213319. [CrossRef]

26. Liao, Y.; Matsagar, B.M.; Wu, K.C. Metal-Organic Framework (MOF)-Derived Effective Solid Catalysts for Valorization of Lignocellulosic Biomass. ACS Sustain. Chem. Eng. 2018, 6, 13628-13643. [CrossRef]

27. Rossetti, I.; Lasso, J.; Compagnoni, M.; De Guido, G.; Pellegrini, L. H2 production from bioethanol and its use in fuel-cells. Chem. Eng. Trans. 2015, 43, 229-234.

28. Rossetti, I.; Gallo, A.; Santo, V.D.; Bianchi, C.L.; Nichele, V.; Signoretto, M.; Finocchio, E.; Ramis, G.; Di Michele, A. Nickel catalysts supported over TiO2, SiO2and ZrO2for the steam reforming of glycerol. ChemCatChem 2013, 5, 294-306. [CrossRef]

29. Nichele, V.; Signoretto, M.; Pinna, F.; Menegazzo, F.; Rossetti, I.; Cruciani, G.; Cerrato, G.; Di Michele, A. Ni/ZrO2 catalysts in ethanol steam reforming: Inhibition of coke formation by CaO-doping. Appl. Catal. B Environ. 2014, 150-151, 12-20. [CrossRef]

30. Rossetti, I.; Biffi, C.; Bianchi, C.L.; Nichele, V.; Signoretto, M.; Menegazzo, F.; Finocchio, E.; Ramis, G.; Di Michele, A. Ni/SiO2 and $\mathrm{Ni} / \mathrm{ZrO} 2$ catalysts for the steam reforming of ethanol. Appl. Catal. B Environ. 2012, 117-118, 384-396. [CrossRef]

31. Rossetti, I.; Lasso, J.; Finocchio, E.; Ramis, G.; Nichele, V.; Signoretto, M.; Di Michele, A. TiO2-supported catalysts for the steam reforming of ethanol. Appl. Catal. A Gen. 2014, 477, 42-53. [CrossRef]

32. Compagnoni, M.; Tripodi, A.; Di Michele, A.; Sassi, P.; Signoretto, M.; Rossetti, I. Low temperature ethanol steam reforming for process intensification: New $\mathrm{Ni} / \mathrm{MxO}-\mathrm{ZrO} 2$ active and stable catalysts prepared by flame spray pyrolysis. Int. J. Hydrogen Energy 2017, 42, 28193-28213. [CrossRef]

33. Rossetti, I.; Bonelli, B.; Ramis, G.; Bahadori, E.; Nasi, R.; Aronne, A.; Esposito, S. New Insights into the Role of the Synthesis Procedure on the Performance of Co-Based Catalysts for Ethanol Steam Reforming. Top. Catal. 2018, 61, 1734-1745. [CrossRef]

34. Di Michele, A.; Dell'Angelo, A.; Tripodi, A.; Bahadori, E.; Sànchez, F.; Motta, D.; Dimitratos, N.; Rossetti, I.; Ramis, G.; Sanchez, F. Steam reforming of ethanol over Ni/MgAl2O4 catalysts. Int. J. Hydrogen Energy 2019, 44, 952-964. [CrossRef]

35. Rossetti, I.; Compagnoni, M.; Finocchio, E.; Ramis, G.; Di Michele, A.; Zucchini, A.; Dzwigaj, S. Syngas production via steam reforming of bioethanol over Ni-BEA catalysts: A BTL strategy. Int. J. Hydrogen Energy 2016, 41, 16878-16889. [CrossRef]

36. Ramis, G.; Rossetti, I.; Finocchio, E.; Compagnoni, M.; Signoretto, M.; Di Michele, A. Metal dispersion and interaction with the supports in the coke production over ethanol steam reforming catalysts. Prog. Clean Energy 2015, 1, 695-711. [CrossRef]

37. Nichele, V.; Signoretto, M.; Menegazzo, F.; Rossetti, I.; Cruciani, G. Hydrogen production by ethanol steam reforming: Effect of the synthesis parameters on the activity of Ni/TiO2 catalysts. Int. J. Hydrogen Energy 2014, 39, 4252-4258. [CrossRef]

38. Rossetti, I.; Lasso, J.; Nichele, V.; Signoretto, M.; Finocchio, E.; Ramis, G.; Di Michele, A. Silica and zirconia supported catalysts for the low-temperature ethanol steam reforming. Appl. Catal. B Environ. 2014, 150-151, 257-267. [CrossRef]

39. Vaidya, P.D.; Rodrigues, A.E. Glycerol reforming for hydrogen production: A review. Chem. Eng. Technol. 2009, 32, 1463-1469. [CrossRef]

40. Hirai, T.; Ikenaga, N.-O.; Miyake, T.; Suzuki, T. Production of hydrogen by steam reforming of glycerin on ruthenium catalyst. Energy Fuels 2005, 19, 1761-1762. [CrossRef]

41. Cui, Y.; Galvita, V.; Rihko-Struckmann, L.K.; Lorenz, H.; Sundmacher, K. Steam reforming of glycerol: The experimental activity of La1-Ce NiO3 catalyst in comparison to the thermodynamic reaction equilibrium. Appl. Catal. B Environ. 2009, 90, 29-37. [CrossRef]

42. Iriondo, A.; Barrio, V.; Cambra, J.; Arias, P.; Güemez, M.; Navarro, R.; Sanchez-Sanchez, M.; Fierro, J.L.G. Influence of La2O3 modified support and $\mathrm{Ni}$ and $\mathrm{Pt}$ active phases on glycerol steam reforming to produce hydrogen. Catal. Commun. 2009, 10, 1275-1278. [CrossRef]

43. Iriondo, A.; Barrio, V.L.; Cambra, J.F.; Arias, P.L.; Güemez, M.B.; Yerga, R.M.N.; Sánchez-Sánchez, M.C.; Fierro, J.L.G. Hydrogen production from glycerol over nickel catalysts supported on $\mathrm{Al} 2 \mathrm{O} 3$ modified by Mg, Zr, Ce or La. Top. Catal. 2008, 49, 46-58. [CrossRef]

44. Compagnoni, M.; Lasso, J.; Di Michele, A.; Rossetti, I. Flame-pyrolysis-prepared catalysts for the steam reforming of ethanol. Catal. Sci. Technol. 2016, 6, 6257. [CrossRef]

45. Rossetti, I.; Buchneva, O.; Biffi, C.; Rizza, R. Effect of sulphur poisoning on perovskite catalysts prepared by flame-pyrolysis. Appl. Catal. B Environ. 2009, 89, 383-390. [CrossRef]

46. Available online: https://www.icdd.com/pdfsearch/ (accessed on 1 October 2020).

47. Nichele, V.; Signoretto, M.; Pinna, F.; Ghedini, E.; Compagnoni, M.; Rossetti, I.; Cruciani, G.; Di Michele, A. Bimetallic Ni-Cu catalysts for the low-temperature ethanol steam reforming: Importance of metal-support interactions. Catal. Lett. 2015, 145, 549-558. [CrossRef]

48. Finocchio, E.; Rossetti, I.; Ramis, G. Redox properties of Co- and Cu-based catalysts for the steam reforming of ethanol. Int. J. Hydrogen Energy 2013, 38, 3213-3225. [CrossRef] 
49. Nichele, V.; Signoretto, M.; Menegazzo, F.; Gallo, A.; Dal Santo, V.; Cruciani, G.; Cerrato, G. Glycerol steam reforming for hy-drogen production: Design of Ni supported catalysts. Appl. Catal. B Environ. 2012, 111-112, 225-232. [CrossRef]

50. Gallo, A.; Pirovano, C.; Ferrini, P.; Marelli, M.; Psaro, R.; Santangelo, S.; Faggio, G.; Dal Santo, V. Influence of reaction parameters on the activity of ruthenium based catalysts for glycerol steam reforming. Appl. Catal. B Environ. 2012, 121-122, 40-49. [CrossRef]

51. Imai, H.; Yamawaki, M.; Li, X. Direct synthesis of methane from glycerol by using silica-modified nickel catalyst. J. Japan Pet. Inst. 2017, 60, 311-321. [CrossRef]

52. Bartholomew, C.H. Mechanisms of catalyst deactivation. Appl. Catal. A Gen. 2001, 212, 17-60. [CrossRef]

53. Ramesh, S.; Yang, E.H.; Jung, J.S.; Moon, D.J. Copper decorated perovskite an efficient catalyst for low temperature hydrogen production by steam reforming of glycerol. Int. J. Hydrogen Energy 2015, 40, 11428-11435. [CrossRef]

54. Ramesh, S.; Venkatesha, N.J. Template free synthesis of NI-perovskite: An E_cient catalyst for hydrogen production by steam reforming of bioglycerol. ACS Sustain. Chem. Eng. 2017, 5, 1339-1346. [CrossRef] 